\title{
Applications of crowdsourcing in health: an overview
}

\author{
Kerri Wazny \\ Centre for Global Health Research, \\ Usher Institute of Informatics and \\ Population Sciences, University of \\ Edinburgh, Edinburgh, UK
}

Background Crowdsourcing is a nascent phenomenon that has grown exponentially since it was coined in 2006. It involves a large group of people solving a problem or completing a task for an individual or, more commonly, for an organisation. While the field of crowdsourcing has developed more quickly in information technology, it has great promise in health applications. This review examines uses of crowdsourcing in global health and health, broadly.

Methods Semantic searches were run in Google Scholar for "crowdsourcing," "crowdsourcing and health," and similar terms. 996 articles were retrieved and all abstracts were scanned. 285 articles related to health. This review provides a narrative overview of the articles identified.

Results Eight areas where crowdsourcing has been used in health were identified: diagnosis; surveillance; nutrition; public health and environment; education; genetics; psychology; and, general medicine/other. Many studies reported crowdsourcing being used in a diagnostic or surveillance capacity. Crowdsourcing has been widely used across medical disciplines; however, it is important for future work using crowdsourcing to consider the appropriateness of the crowd being used to ensure the crowd is capable and has the adequate knowledge for the task at hand. Gamification of tasks seems to improve accuracy; other innovative methods of analysis including introducing thresholds and measures of trustworthiness should be considered.

Conclusion Crowdsourcing is a new field that has been widely used and is innovative and adaptable. With the exception of surveillance applications that are used in emergency and disaster situations, most uses of crowdsourcing have only been used as pilots. These exceptions demonstrate that it is possible to take crowdsourcing applications to scale. Crowdsourcing has the potential to provide more accessible health care to more communities and individuals rapidly and to lower costs of care.

\section{Correspondence to:}

Kerri Wazny

Centre for Global Health Research

Usher Institute of Population Health Sciences and Informatics

University of Edinburgh

Old Medical School

Teviot Place

Edinburgh EH8 9AG

United Kingdom

kerri.wazny@ed.ac.uk
The term crowdsourcing was coined a decade ago in Howe's 2006 Wired article and the field of crowdsourcing in academia and industry has since grown exponentially [1-3]. Despite recent interest in the field, the actual practice of crowdsourcing has been in use for hundreds of years [3-5]. Some of the early uses of crowdsourcing include Britain's Longitude Act and Galton's report of an experiment where 787 people collectively and accurately guessed the weight of an ox $[3,6,7]$.

Crowdsourcing refers to a large group of people collectively solving a problem or completing a task for an individual or an organisation. Its definition 
is disputed $[2,8,9]$. The terms citizen science, mHealth, and wisdom of the crowds are often incorrectly used interchangeably with crowdsourcing [9-11]. Crowdsourcing differs from citizen science in that it does not necessarily involve laypersons contributing and it can be using mHealth technology but this is not a requirement. 'Wisdom of the crowds' refers to a specific type of crowdsourcing that capitalises on people's collective knowledge; there are examples of crowdsourcing that do not require people to use knowledge in order to complete tasks. An in-depth exploration of defining crowdsourcing is reviewed elsewhere [8].

The field of crowdsourcing has developed in information technology or business, but crowdsourcing can be a promising tool in health, and in global health in particular. It is rapid, low cost, and can collect a huge amount of information from a large number of people [3,12-15]. It also is a flexible method that has the potential to cover a variety of research, including quickly evolving epidemiological research and traditional behavioural research. It can cover unpredictable events, produce novel discoveries, and can also be used to raise public awareness [3,12-20]. Research in crowdsourcing has also been shown to be at least as accurate as traditional research methods $[10,21]$.

This review examines uses of crowdsourcing in health, and in global health in particular.

Box 1. Crowdsourcing semantic searches conducted in Google Scholar.

1. "Crowdsourcing" a. Up to 25 pages

2. "Crowdsourcing" and "Health" a. Up to 15 pages

3. "Crowdsourcing" and "Immunology" a. Up to 5 pages

4. "Crowdsourcing" and "Genetics" a. Up to 9 pages

5. "Crowdsourcing" and "Public Health" a. Up to 20 pages

6. "Crowdsourcing" and "Disease" a. Up to 25 pages

7. "Crowdsourcing" and "Surveillance" a. To 20 pages

8. "Crowdsourcing" and "Diagnosis" a. Up to page 14

\section{METHODS}

This review is the second part of a larger review on crowdsourcing [8]. Previously conducted reviews missed many peer-reviewed papers, due to poor indexing of crowdsourcing [3,22,23]; thus, Google Scholar was used to search peer-reviewed and grey literature for articles related to crowdsourcing and health. Semantic searches were conducted by combining 'crowdsourcing' with health-related terms, including 'health, ' 'public health,' 'genetics,' and 'disease,' etc. A full list of the sematic searches can be found in Box 1. Searches were conducted in August 2015 and titles of results were scanned directly from within Google Scholar. Pages of search results within Google Scholar were scanned until it was clear that the results retrieved were no longer relevant. Box 1 provides details on how many pages of Google Scholar results were searched for each semantic search. 996 articles were identified through the Google Scholar search, of which 375 were discarded as duplicates or as irrelevant (not crowdsourcing) once abstracts were read. 285 of the articles related to various aspects of health. All 285 articles were read and organised into categories; as this is a narrative review, this article reports on the clusters that formed most prominently after organising the articles into categories in order to give an overview of the ways in which crowdsourcing is being used in health.

This review provides an overview of some of the ways crowdsourcing has been used, using a selection of the papers identified as illustration.

\section{RESULTS}

Eight areas of importance were identified: (i) diagnosis; (ii) surveillance; (iii) nutrition; (iv) public health and environment; (v) education; (vi) genetics; (vii) psychology; and, (viii) general medicine/other. Table 1 provides an in-depth description of the individual studies.

\section{Diagnosis}

Diagnosis was the most common usage of crowdsourcing in health. Crowdsourcing has been used multiple times for diagnosing malaria, specifically, and then for grading images in order to diagnose various conditions and diseases [24-28,30-32,88]. It has also been used to assist physicians in diagnosing conditions $[34,35]$.

Three articles described the BioGames project, where laypersons were able to diagnose red blood cells (RBCs) infected with malaria [24-26]. Mavandadi et al. argue that rapid diagnostics for malaria are expensive, unreliable due to heat/stability issues and not trusted by health care workers (HCWs) in lowand middle-income countries and that gamification of malaria diagnosis could improve the management 
Table 1. Description of studies included in overview

\begin{tabular}{|c|c|c|c|c|}
\hline Reference & Category & TopIC & How GROWDSOURCING IS USED & Results \\
\hline $\begin{array}{l}\text { Mavandadi et al. } \\
\text { [24], Ozcan [25] }\end{array}$ & Diagnosis & $\begin{array}{l}\text { Malaria } \\
\text { diagnosis }\end{array}$ & $\begin{array}{l}\text { Uses gaming (BioGames) to diagnose malaria } \\
\text { parasites. Gamers are given a tutorial, and } \\
\text { must achieve accuracy of }>99 \% \text { in training } \\
\text { game before playing real game. Gamers asked } \\
\text { to label cell as infected vs healthy. }\end{array}$ & $\begin{array}{l}\text { Gamer diagnoses had an accuracy of } 99 \% \text {, } \\
\text { sensitivity of } 95.1 \% \text { and specificity of } 99.4 \% \text {. } \\
\text { Authors suggests that gaming could be a } \\
\text { viable option for telepathology. }\end{array}$ \\
\hline Feng et al. [26] & Diagnosis & $\begin{array}{l}\text { Malaria } \\
\text { - education } \\
\text { through } \\
\text { diagnosis }\end{array}$ & $\begin{array}{l}\text { Based off BioGames app }[24,25] \text {, used } \\
\text { gamification to train non-experts to diagnose } \\
\text { malaria parasites and compared diagnoses to } \\
\text { experts. }\end{array}$ & $\begin{array}{l}\text { BioGames has achieved diagnostic accuracy } \\
\text { comparable to that of experts when scores } \\
\text { from individual non-experts are aggregated } \\
\text { and the crowd size is large. }\end{array}$ \\
\hline $\begin{array}{l}\text { Luengo-Oroz et } \\
\text { al. [27] }\end{array}$ & Diagnosis & $\begin{array}{l}\text { Malaria } \\
\text { diagnosis }\end{array}$ & $\begin{array}{l}\text { A crowdsourcing game (MalariaSpot) was } \\
\text { designed using malaria-positive blood films. } \\
\text { Players were asked to tag as many malarial } \\
\text { parasites as possible in } 1 \text { min and given }\end{array}$ & $\begin{array}{l}\text { Combination of games or more resulted in } \\
\text { extremely accurate identification of malarial } \\
\text { parasites ( } 99 \% \text { accuracy). }\end{array}$ \\
\hline
\end{tabular}

\begin{tabular}{llll}
\hline Mitry et al. [28] & Diagnosis & $\begin{array}{l}\text { Detecting } \\
\text { glaucomatous } \\
\text { optic } \\
\text { neuropathy }\end{array}$ & $\begin{array}{l}\text { Uses Amazon Mechanical Turk to study } \\
\text { viability of crowdsourcing to detect glaucoma- } \\
\text { tous optic neuropathy. Turkers were asked to } \\
\text { classify images as normal or abnormal, with } \\
\text { each image being classified 20 times. }\end{array}$ \\
\hline Brady et al. [29] & Diagnosis & $\begin{array}{l}\text { Grading of } \\
\text { diabetic } \\
\text { retinopathy }\end{array}$ & $\begin{array}{l}\text { Uses Amazon Mechanical Turk for classifying } \\
\text { fundus photos of diabetic retinopathy. }\end{array}$
\end{tabular}

Authors had two groups, one did not restrict and the other restricted to high-performing Turkers. Sensitivity was high across both, ranging from $83 \%-88 \%$, but specificity was poor, ranging between $35 \%-43 \%$.

$81.3 \%$ of images were correctly classified in an average time of $25 \mathrm{~s}$ per image. However, Turkers struggled to specify the level of severity.

\begin{tabular}{|c|c|c|c|}
\hline do Reis et al. [30] & Diagnosis & $\begin{array}{l}\text { Large scale } \\
\text { molecular } \\
\text { pathology } \\
\text { studies in } \\
\text { cancer }\end{array}$ & $\begin{array}{l}\text { Used } 98293 \text { citizen scientists to access cell } \\
\text { slider web page and score tumor markers. } \\
\text { Specifically, citizen scientists scored sub-imag- } \\
\text { es of tissue microarray cores labelled for } \\
\text { estrogen receptor prognosis. }\end{array}$ \\
\hline
\end{tabular}

The citizen scientists performed well in identifying cancer (area under ROC curve $0.95,95 \%$ CI 0.94 to 0.96 ), and estrogen receptor status $(0.97,95 \%$ CI 0.96 to 0.97$)$, and was similar to trained pathologists.

Gehl et al. [31] Diagnosis Skin self-exam- Conducted a physical crowdsourcing exercises
ination for in a mall, recruiting 500 participants and melanoma teaching basic skin self-examination techniques. Implemented various thresholds to improve crowd results.

Xiang et al. [32] Diagnosis $\quad \begin{aligned} & \text { Diagnosing } \\ & \text { medical imag }\end{aligned}$

Because there is a lack of high-level experts in rural China, the authors investigated whether crowdsourcing could be used to diagnose medical images. $2^{\text {nd }}-$ or $3^{\text {rd }}$ - year graduate students with a medical imaging major participated. Using a 19\% threshold, $90 \%$ of melanomas were identified and $72 \%$ of non-melanomas, and with a $65 \%$ threshold, $67 \%$ of melanomas were identified and $100 \%$ of non-melanomas. Authors recommend the 19\% threshold.

The average accuracy was $39.54 \%$, with the best student only making the correct diagnosis $50 \%$ of the time. Using a machine learning algorithm with majority voting, combined with crowdsourcing, which learns the students' mistakes, accuracy can increase to $80 \%$.

\begin{tabular}{lll}
\hline Cheng et al. [33] Diagnosis & $\begin{array}{l}\text { Diagnosing } \\
\text { medical } \\
\text { illnesses }\end{array}$ & $\begin{array}{l}\text { Investigated the feasibility of using crowd- } \\
\text { sourcing for diagnosing medical conditions } \\
\text { with case descriptions of varying difficulty, } \\
\text { posted on Amazon Mechanical Turk, O'Desk, } \\
\text { and web forums. }\end{array}$
\end{tabular}

Web forums were ineffective. Turkers diagnosed easy to diagnose cases. O'Desk workers were able to diagnose easy cases, but were more likely to express caution when providing diagnoses for any complicated cases, and some refused to provide diagnoses.

\begin{tabular}{lll}
\hline Sims et al. [34] Diagnosis & $\begin{array}{l}\text { Point-of-care } \\
\text { problem } \\
\text { solving for } \\
\text { clinicians }\end{array}$ & $\begin{array}{l}\text { Authors reports clinicians' experiences using a } \\
\text { crowdsourcing application for point-of-care } \\
\text { problem solving, where clinicians post } \\
\text { problems via an app and these are answered } \\
\text { by verified users and viewable by users in that } \\
\text { user's provider group }\end{array}$
\end{tabular}

Over $80 \%$ of respondents felt that app could have a positive impact on patient care, medical education, referrals, and difficult diagnoses. Both non-users and users were surveyed, and non-users were more concerned about potential to disrupt workflow.

\begin{tabular}{|c|c|c|c|c|}
\hline $\begin{array}{l}\text { McComb \& Bond } \\
{[35]}\end{array}$ & Diagnosis & $\begin{array}{l}\text { Increasing } \\
\text { diagnostic } \\
\text { accuracy } \\
\text { among junior } \\
\text { physicians }\end{array}$ & $\begin{array}{l}\text { Developed and piloted a web-based } \\
\text { crowdsourcing software to enable junior } \\
\text { doctors to upload cases and receive feedback } \\
\text { from expert physicians, with an element of } \\
\text { gamification using reward points. }\end{array}$ & $\begin{array}{l}\text { The web interface improved diagnostic ability } \\
\text { of junior clinicians, but senior clinicians were } \\
\text { less actively involved, due to workload, time, } \\
\text { availability and reluctance to embrace the new } \\
\text { technology. }\end{array}$ \\
\hline Freifeld et al. [36] & Surveillance & $\begin{array}{l}\text { Review of } \\
\text { participatory } \\
\text { epidemiology }\end{array}$ & $\begin{array}{l}\text { The author provides a review of participatory } \\
\text { epidemiology, including FrontlineSMS, } \\
\text { Ushahidi, GeoChat, Asthmapolis, and } \\
\text { Outbreaks Near Me. }\end{array}$ & $\begin{array}{l}\text { While, at the time of this review, participatory } \\
\text { epidemiology platforms were relatively new, } \\
\text { there were already palatable benefits. }\end{array}$ \\
\hline $\begin{array}{l}\text { Chunara et al. } \\
\text { [37] }\end{array}$ & Surveillance & $\begin{array}{l}\text { Online } \\
\text { self-reported } \\
\text { influenza }\end{array}$ & $\begin{array}{l}\text { Volunteer users filled in a short survey } \\
\text { regarding flu symptoms, and enrolling family } \\
\text { members. Volunteers enter information } \\
\text { weekly, and a map of influenza is available to } \\
\text { them. }\end{array}$ & $\begin{array}{l}9300 \text { users in August } 2012 \text { throughout the } \\
\text { US. }\end{array}$ \\
\hline
\end{tabular}


Table 1. Continued

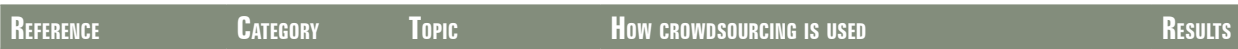

Michael \& Geleta Surveillance Global disease Describes a smartphone app, Click Clinica, to [38]

surveillance increase the identification of infectious diseases globally. App contains clinical guidelines, and questions to confirm diagnosis and resistance information.

When 'live' for one month, app had already been downloaded over 1000 times and 600 disease notifications had been added. Data was treated as most trusted depending on information provided by submitter (ie, if email, contact details submitted).

\begin{tabular}{lll}
\hline Qureshi et al. $\quad$ Surveillance & $\begin{array}{l}\text { Disease } \\
\text { outbreak } \\
\text { monitoring }\end{array}$
\end{tabular}

Uses Lady Health Workers in rural areas of

The program was able to display regional Pakistan to report via SMS health information to an electronic disease monitoring system (Jaroka TeleHealthcare System), which provides geospatial location of patients for doctors, medical experts and health officials.

\section{Lwin et al. [40] Surveillance Dengue} surveillance

\section{Reports on an app, "Mo-Buzz," which}

contains predictive surveillance, civic engagement, and health communication. Citizens use the app or social media to report breeding sites, symptoms and mosquito bites. Using this information, tailored health messages are delivered to individuals living in hot spots. Predictive surveillance predicts outbreaks using this information, combined with weather and other data.

\begin{tabular}{|c|c|c|c|}
\hline $\begin{array}{l}\text { Chunara et al. } \\
\text { [41] }\end{array}$ & Surveillance & $\begin{array}{l}\text { Malaria } \\
\text { surveillance in } \\
\text { India }\end{array}$ & $\begin{array}{l}\text { Amazon Mechanical Turk was used to solicit } \\
\text { self-reports about malaria diagnosis and } \\
\text { related information. }\end{array}$ \\
\hline
\end{tabular}

\begin{tabular}{llll}
\hline Freeman [42] & $\begin{array}{l}\text { Identifying } \\
\text { erroneous } \\
\text { global } \\
\text { burden of } \\
\text { disease }\end{array}$ & Surveillance & $\begin{array}{l}\text { A crowdsourcing platform was designed, } \\
\text { comparing the effect of gamification, to } \\
\text { identify erroneous estimates in the global } \\
\text { burden of disease database. }\end{array}$
\end{tabular}

estimates

Harrison et al. Nutrition

[43]

\begin{tabular}{lcl} 
& & illness \\
\hline Kang et al. [44] & Nutrition & $\begin{array}{l}\text { Using Yelp } \\
\text { reviews to } \\
\text { correlated with } \\
\text { failed hygiene } \\
\text { inspections }\end{array}$ \\
\hline $\begin{array}{lll}\text { Dunford et al. } & \text { Nutrition } & \begin{array}{l}\text { Healthier food } \\
\text { [45] }\end{array} \\
& & \text { an app using }\end{array}$
\end{tabular}

Restaurant Used poor Yelp reviews, specifically those

reviews to iden- using the words sick, vomit, diarrhea, or food tify foodborne poisoning, to identify food poisoning in New York City restaurants

Authors review Yelp, examining whether reviews are correlated with failing hygiene inspections.

patterns for diseases, as well as a disease outbreak that was due to a mass migration of internally displaced persons. The authors reported that the program helps identify whether an epidemic is imminent.

The paper discusses some difficulties with the app, including verifying images due to clarity and receiving multiple images/submissions of the same breeding site. It does not report on the impact of the app on dengue outbreaks.

Authors gained information of distribution of malaria species in India, and estimated burden, which coincided with official public health reports.

Overall, the classifications were matched to a GBD expert $86 \%$ of the time. Adding gamification increased accuracy significantly, with gamified users identifying 1.7 times more trends than those using a standard (non-gamified) interface.

3 cases of outbreaks met the Department of Health and Mental Hygiene criteria for a food outbreak that were previously unreported.

The authors find that poor Yelp reviews are correlated with having failed hygiene inspections in Seattle.

\section{An app, FoodSwitch, uses crowdsourced} submissions of food products in Australia Crowdsourced submissions are scanned by SKU and then labelled red, green, or yellow to make it easier for consumers to identify healthy foods.

\begin{tabular}{lll}
\hline $\begin{array}{l}\text { Noronha et al. Nutrition } \\
\text { [46] }\end{array}$ & $\begin{array}{l}\text { Nutritional } \\
\text { analyses using } \\
\text { photos of food } \\
\text { " "PlateMate" }\end{array}$ & $\begin{array}{l}\text { Uses Amazon Mechanical Turk, and a } \\
\text { step-by-step process to estimate calories, fat, } \\
\text { carbohydrates, and protein. First, every food } \\
\text { item in a photo is tagged, then identified, then } \\
\text { measured, each in a separate HIT. }\end{array}$ \\
&
\end{tabular}

\begin{tabular}{llll}
\hline $\begin{array}{l}\text { Turner-McGrievy } \\
\text { et al. [47] Nutrition }\end{array}$ & $\begin{array}{l}\text { Nutritional } \\
\text { analysis of } \\
\text { photos of food } \\
\text { - "Eatery App" }\end{array}$ & $\begin{array}{l}\text { Users in the Eatery App post a photo of food, } \\
\text { asking other users how healthy it is, and } \\
\text { receive crowdsourcing ratings. The goal is to } \\
\text { modify diets based on the feedback. }\end{array}$
\end{tabular}

FoodSwitch has been downloaded by 400000 users and more than 30000 crowdsourced products have been added to the app.

The application's error rate was not significantly different from MealSnap (another application) or dieticians. Challenges identified include tagging the entire food item (otherwise it may only be partially measured at a latter stage), or correctly identifying the food item.

Overall, peer and expert ratings were highly correlated across the US and Europe. Several food categories led to higher healthiness scores among peers (fruit, vegetables, whole

\begin{tabular}{lll}
\hline $\begin{array}{l}\text { Moorhead et al. Nutrition } \\
\text { [48] }\end{array}$ & $\begin{array}{l}\text { Identifying } \\
\text { calories in } \\
\text { meals using a } \\
\text { smartphone }\end{array}$ & $\begin{array}{l}\text { A mobile application was used to pilot the } \\
\text { feasibility of a smartphone app for crowd- } \\
\text { sourcing with non-experts to identify calories. } \\
\text { Training was provided to non-experts, who } \\
\text { were asked a month later to estimate calories } \\
\text { of food using a photo. A crowd of experts and } \\
\text { non-experts was investigated. }\end{array}$ \\
\hline
\end{tabular}
grains, legumes, nuts and seeds) and lower healthiness scores among peers (fast food, refined grains, red meat, cheese, savory snacks, desserts, and sugar-sweetened beverages) Both the crowd of experts and the crowd of non-experts outperformed individual experts or individual non-experts. The expert group estimated the calories significantly more accurately than the non-expert group. 
Table 1. Continued

$\begin{array}{lll}\text { RefFerence } & \text { Category } & \text { Topic } \\ \begin{array}{l}\text { Bevelander et al. } \\ \text { [49] }\end{array} & \text { Nutrition } & \begin{array}{l}\text { Predictors of } \\ \text { obesity }\end{array}\end{array}$

Participants recruited via reddit, and asked to pose and answer questions regarding childhood predictors of adult BMI for the purpose of generating predictors for a statistical model. Users answered previous questions and posed new ones.
How GROWDSOURGING IS USED

ResulTS

Final sample of 532, 56 new questions identified, 16 of which were highly correlated with adult obesity. Exploratory factor analysis identified 4 factors (home environment, psychosocial well-being, healthy lifestyle, and family history and biological factors). Study identified well-known predictors, but also predictors that had not been well-studied previously. Data collection was rapid.

\begin{tabular}{ll}
\hline $\begin{array}{l}\text { Bongard et al. Nutrition } \\
\text { [50] }\end{array}$ & $\begin{array}{l}\text { Predictors of } \\
\text { behavioural } \\
\text { outcomes }\end{array}$
\end{tabular}

Participants recruited via reddit were asked to pose and answer questions regarding predictors of adult obesity and energy consumptions. The questions and their answers were used to develop predictors in a statistical model.

\begin{tabular}{lll}
\hline Patel et al. [51] & Public & Measuring \\
& Health \& & second-hang \\
& Environment & smoking in \\
& vehicles
\end{tabular}

\begin{tabular}{lll}
\hline Ilakkuvan et & Public & Point-of-Sale \\
al.[52] & Health \& & Tobacco \\
& Environment &
\end{tabular}

Environment
Developed an app to be used while driving (by passengers) to measure smoking in other vehicles. Smartphone collects data on number of cars passing (denominator) and user inputs when he/she sees a person smoking in the car, and if so, whether there are other occupants and if occupants are children

Uses Amazon Mechanical Turk and image annotation, with micro-tasks (using a zoom feature) to identify point-of-sale tobacco advertising, and compared to field-raters.

\begin{tabular}{lll}
\hline Kim et al. [53] & Public & Point-of-Sale \\
& Health \& & Tobacco \\
& Environment &
\end{tabular}

Authors used Gigwalk, which is a mobile crowdsourcing application, to request workers to physically conduct point-of-sale tobacco monitoring. Workers were provided with a manual, but no training, and their work was compared to trained data collectors.

\begin{tabular}{lll}
\hline Hipp [54] & $\begin{array}{l}\text { Public Heath } \\
\text { \& Environ- } \\
\text { ment }\end{array}$ & $\begin{array}{l}\text { Built environ- } \\
\text { ment } \\
\text { surveillance }\end{array}$ \\
\hline Castell et al. [55] & $\begin{array}{l}\text { Public } \\
\text { Health \& }\end{array}$ & $\begin{array}{l}\text { Air pollution } \\
\text { sensors }\end{array}$ \\
& Environment &
\end{tabular}

Used crowdsourcing to annotate and evaluate captured scenes from 23000 webcams.

Authors describe two projects where sensors are provided to citizens and linked to smartphones, measuring air pollution. The hope is that the sensors will change behaviour patterns, causing citizens to avoid polluted areas, while also producing a map of pollution for cities in which sensors are in use.

\begin{tabular}{lll}
\hline Turner et al. [56] & Public & Testing \\
& Health \& & multilingual \\
& Environment & health \\
& & promotion
\end{tabular}

Using Amazon Mechanical Turk, the authors tested promotional health materials with both native English and native Spanish speakers.

\begin{tabular}{lll}
\hline Hildebrand et al. & Public & Including \\
[57] & Health \& & youth \\
& Environment & perspectives in \\
& & HIV/AIDS \\
& messaging
\end{tabular}

A website, CrowdOutAIDS.org, was created to enable youth to be involved in shaping policies, to set priorities and influence actions at UNAIDS. The website intended to connect a community of young people and collect their experiences and ideas and to provide a means to synthesize the information collected from youth globally. Questions were asked in community and online forums in order to ensure youth without internet access were able to participate.

\begin{tabular}{|c|c|c|c|}
\hline $\begin{array}{l}\text { Merchant et al. } \\
{[19,20]}\end{array}$ & $\begin{array}{l}\text { Public } \\
\text { Health \& } \\
\text { Environment }\end{array}$ & $\begin{array}{l}\text { Mapping } \\
\text { Automated } \\
\text { External } \\
\text { Defibrillators } \\
\text { (AEDs) }\end{array}$ & $\begin{array}{l}\text { Developed a crowdsourcing challenge to map } \\
\text { AEDs in Philadelphia, which was advertised } \\
\text { on TV and radio. Contestants registered via } \\
\text { Web or an app, and photographed AED } \\
\text { locations (along with AED information) } \\
\text { around the city for a chance to win US\$ } \\
10000 \text { prize. }\end{array}$ \\
\hline
\end{tabular}

Study lasted 8 weeks. 313 teams and individuals participated and those $>40$ submitted more entries than younger participants. 1429 submissions were received.

Authors were able to reach a more diverse population than with traditional data collection methods, more quickly, and for less cost. They were able to gain more nuanced suggestions to tailor their materials to different populations.

Found excellent inter-rater agreement, with AUC averaging over 0.95 (with sensitivity analyses). Author recommends further testing of photograph annotation tools in future crowd and trained data collectors on most computed in much so that kappa couldn't be perfect.

Once annotated, study found changes in behaviour after changes in built environment.

The results of these projects were not described.

AIDS was able to collect information across the globe, highlight similarities and differences from youth both globally and within regions, and to enable youth to influence their policy. 
Table 1. Continued

\begin{tabular}{|c|c|c|c|c|}
\hline ReFERENGE & Category & TopIC & How crowdsourcing IS USED & Results \\
\hline Tucker et al. [58] & $\begin{array}{l}\text { Public } \\
\text { Health \& } \\
\text { Environment }\end{array}$ & $\begin{array}{l}\text { Contest for } \\
\text { promotional } \\
\text { videos HIV } \\
\text { testing } \\
\text { programs }\end{array}$ & $\begin{array}{l}\text { Authors launched a contest for promotional } \\
\text { videos to encourage HIV testing in China. }\end{array}$ & $\begin{array}{l}\text { Seven eligible videos were received in } 2 \text { mo. } \\
\text { Videos were judged on reaching untested } \\
\text { individuals, engaging the community, and } \\
\text { creating excitement around HIV testing. }\end{array}$ \\
\hline Bow et al. [59] & Education & $\begin{array}{l}\text { Study materials } \\
\text { for medical } \\
\text { students }\end{array}$ & $\begin{array}{l}\text { The authors used Google Drive and Java to } \\
\text { enable students in the preclinical medicine } \\
\text { program to continuously submit and } \\
\text { collaboratively edit study questions through- } \\
\text { out the course. Prior to the exam, Java turned } \\
\text { the study questions into flashcards. }\end{array}$ & $\begin{array}{l}16150 \text { study questions were created, and the } \\
\text { students in that year outperformed students of } \\
\text { the previous year in all exams. }\end{array}$ \\
\hline Plenge et al. [60] & Genetics & $\begin{array}{l}\text { Genetic } \\
\text { prediction of } \\
\text { Rheumatoid } \\
\text { Arthritis }\end{array}$ & $\begin{array}{l}\text { Authors describe a challenge by DREAM and } \\
\text { SAGE, which is a crowdsourcing competition, } \\
\text { to develop genetic predictors of response to } \\
\text { immunosuppressive therapy in rheumatoid } \\
\text { arthritis. }\end{array}$ & $\begin{array}{l}\text { N/A (description was the challenge, but not } \\
\text { the results) }\end{array}$ \\
\hline Ewing et al. [61] & Genetics & $\begin{array}{l}\text { Detecting } \\
\text { somatic } \\
\text { mutations from } \\
\text { cancer genomes }\end{array}$ & $\begin{array}{l}\text { Describes a DREAM challenge, which is a } \\
\text { crowdsourcing competition, to detect somatic } \\
\text { mutations from cancer genomes. Employed } \\
\text { Google Cloud, and had a public, real-time } \\
\text { leaderboard. }\end{array}$ & $\begin{array}{l}\text { Received } 248 \text { submissions from } 21 \text { teams over } \\
\text { approximately } 6 \text { mo. The leaderboard enabled } \\
\text { teams to improve submissions once they had } \\
\text { an initial performance estimate. Finally, } \\
\text { authors aggregated submissions of best-per- } \\
\text { forming teams. }\end{array}$ \\
\hline $\begin{array}{l}\text { Loguercio et al. } \\
\text { [62] }\end{array}$ & Genetics & $\begin{array}{l}\text { Human gene } \\
\text { annotation }\end{array}$ & $\begin{array}{l}\text { Dizeez is a crowdsourcing game where players } \\
\text { match genes with a clue of the disease; players } \\
\text { receive points for selecting the correct } \\
\text { disease-gene match. Players can select a } \\
\text { specific disease area or protein family. } \\
\text { Annotations that are reported across multiple } \\
\text { players receive the highest confidence scores. }\end{array}$ & $\begin{array}{l}\text { In } 9 \text { mo, } 6,941 \text { unique gene-disease } \\
\text { assertions were generated from Dizeez; } 2137 \\
\text { were not found in any gene-disease databases } \\
\text { (OMIM, PharmGKB, or Gene Wiki). } 17 \text { of } \\
\text { these associations occurred more than } 7 \text { times; } \\
\text { these were statistically significant. Authors } \\
\text { examined these through a manual literature } \\
\text { search and found evidence } 14 \text {. }\end{array}$ \\
\hline Burger et al. [63] & Genetics & $\begin{array}{l}\text { Gene mutation } \\
\text { relations }\end{array}$ & $\begin{array}{l}\text { Authors used Amazon Mechanical Turk to } \\
\text { judge associations between genes and } \\
\text { mutations. Genes were taken from the } \\
\text { GenNorm system, and mutations from the } \\
\text { Extractor of Mutations system. Genes and } \\
\text { mutations mentioned in Pubmed were } \\
\text { included, and Turkers were provided with the } \\
\text { abstract(s) mentioning the gene and mutations } \\
\text { and had to judge if they were related. }\end{array}$ & $\begin{array}{l}\text { The authors explored quality control } \\
\text { methods, including repeating experiments on } \\
\text { the same HIT and aggregating those results, } \\
\text { and eliminating any Turker whose perfor- } \\
\text { mance fell below } 50 \% \text { accuracy on control } \\
\text { items. When these were implemented, } \\
\text { accuracy of } 89.9 \% \text { was achieved for a cost of } \\
\text { US } \$ 0.76\end{array}$ \\
\hline $\begin{array}{l}\text { Kido \& Swan } \\
{[64]}\end{array}$ & Genetics & $\begin{array}{l}\text { Exploring } \\
\text { relationship } \\
\text { between genes } \\
\text { and social } \\
\text { intelligence }\end{array}$ & $\begin{array}{l}\text { Using results from personal genomics (My } \\
\text { Quantified Self), and through tracking } \\
\text { personal behavior, the authors explore the } \\
\text { relation between the OXTR gene and social in- } \\
\text { telligence using personality testing }\end{array}$ & $\begin{array}{l}\text { The authors' results were not statistically } \\
\text { significant and need more power; however, } \\
\text { the authors' initial results were in a different } \\
\text { direction than hypothesized. Individuals with } \\
\text { the AG genotype have lower EQ/IRI values } \\
\text { than those with AA, and that an increase in } \\
\text { the A allele's frequency corresponds to } \\
\text { decreased optimism. }\end{array}$ \\
\hline $\begin{array}{l}\text { Krantz \& Berg } \\
{[65]}\end{array}$ & Genetics & $\begin{array}{l}\text { Incidental } \\
\text { findings in } \\
\text { GWAS studies }\end{array}$ & $\begin{array}{l}\text { Authors propose using crowdsourcing to solve } \\
\text { the problem of reporting incidental findings to } \\
\text { populations who have participated in GWAS } \\
\text { studies, given that new knowledge of genetic } \\
\text { diseases is being discovered. }\end{array}$ & $\begin{array}{l}\text { Proposed system: authors propose a binning } \\
\text { system, where crowd sorts findings into } \\
\text { clinically actionable, clinically valid but not } \\
\text { actionable, or no known clinical significance. }\end{array}$ \\
\hline Shapiro et al. [66] & Psychology & $\begin{array}{l}\text { Investigating } \\
\text { whether } \\
\text { Amazon } \\
\text { Mechanical } \\
\text { Turk is } \\
\text { applicable for } \\
\text { mental health }\end{array}$ & $\begin{array}{l}\text { Amazon Mechanical Turk was used, restricted } \\
\text { to US residents, to explore whether an AMT } \\
\text { population would be a viable research tool for } \\
\text { mental health studies. Participants were } \\
\text { followed up one week later. Fabrication of } \\
\text { mental health symptoms was investigated. }\end{array}$ & $\begin{array}{l}\text { The authors found that Turkers were younger, } \\
\text { more educated, white, and more likely to be } \\
\text { middle-class compared to the general } \\
\text { population. The frequency of trauma exposure } \\
\text { and depression. A high proportion of Turkers } \\
\text { had clinically relevant anxiety symptoms, but } \\
\text { this mirrors previous studies of active internet } \\
\text { users. The data were deemed reliable, but } \\
\text { authors recommend similar studies in other } \\
\text { countries. }\end{array}$ \\
\hline $\begin{array}{l}\text { De Choudhury et } \\
\text { al. [67] }\end{array}$ & Psychology & $\begin{array}{l}\text { Measuring } \\
\text { depression in } \\
\text { populations via } \\
\text { social media }\end{array}$ & $\begin{array}{l}\text { Uses Amazon Mechanical Turk to obtain a } \\
\text { survey on depression, and a self-report of } \\
\text { history of depression. The Turkers could } \\
\text { opt-in to share their social media handles. } \\
\text { Handles that were shared were data mined } \\
\text { within a three-month period. }\end{array}$ & $\begin{array}{l}\text { The authors characterize differences between } \\
\text { depressed and non-depressed individuals, } \\
\text { including time of posting, emotion, linguistic } \\
\text { style, engagement and ego-network. These are } \\
\text { used to create a social media depression index } \\
\text { that could be used to predict risk of } \\
\text { depression based on social media posts for } \\
\text { other users. }\end{array}$ \\
\hline
\end{tabular}


Table 1. Continued

\begin{tabular}{ll}
\hline Reference & Category \\
Hong et al. [68] & Psychology
\end{tabular}

TopIC

Advice for people living with autism
How GROWDSOURGING IS USED

Authors wanted to explore using crowdsourcing for advice with people with autism, compared to in-group advice for the same. Questions were selected from online help forums, and authors uploaded those questions to Amazon Mechanical Turk.

\begin{tabular}{|c|c|c|c|}
\hline $\begin{array}{l}\text { Yang \& } \\
\text { Srinivasan [69] }\end{array}$ & Psychology & $\begin{array}{l}\text { Social media } \\
\text { surveillance }\end{array}$ & $\begin{array}{l}\text { Used Amazon Mechanical Turk workers to } \\
\text { write } 20 \text { alternative sentences for each life } \\
\text { satisfaction statement. Statements were then } \\
\text { used to data mine Twitter. }\end{array}$ \\
\hline Love et al. [70] & $\begin{array}{l}\text { General } \\
\text { medicine/ } \\
\text { Other }\end{array}$ & $\begin{array}{l}\text { Collateral } \\
\text { damage of } \\
\text { breast cancer } \\
\text { treatment }\end{array}$ & $\begin{array}{l}\text { A webpage was designed to collect informa- } \\
\text { tion regarding collateral damage of breast } \\
\text { cancer treatment from survivors. }\end{array}$ \\
\hline Carter et al. [71] & $\begin{array}{l}\text { General } \\
\text { medicine/ } \\
\text { Other }\end{array}$ & $\begin{array}{l}\text { Ovarian cancer } \\
\text { awareness }\end{array}$ & $\begin{array}{l}\text { Using Amazon Mechanical Turk, the authors } \\
\text { conduct a survey to explore awareness of } \\
\text { ovarian cancer, using breast cancer as a } \\
\text { control. }\end{array}$ \\
\hline Good et al. [72] & $\begin{array}{l}\text { General } \\
\text { medicine/ } \\
\text { Other }\end{array}$ & $\begin{array}{l}\text { Gene selection } \\
\text { for breast } \\
\text { cancer survival }\end{array}$ & $\begin{array}{l}\text { Created a game called "the Cure" which } \\
\text { trained players prior to entering the main } \\
\text { gaming area. Once in this area, gamers play } \\
\text { against an automated opponent, selecting } \\
\text { genes in a decision tree classifier, with the aim } \\
\text { of surviving. }\end{array}$ \\
\hline Yu et al. [73] & $\begin{array}{l}\text { General } \\
\text { medicine/ } \\
\text { Other }\end{array}$ & $\begin{array}{l}\text { Evaluation of } \\
\text { medical } \\
\text { pictograms }\end{array}$ & $\begin{array}{l}\text { Amazon Mechanical Turk was used to obtain } \\
\text { judgement of meaning behind medical } \\
\text { pictograms. }\end{array}$ \\
\hline
\end{tabular}
was asked whether this was true or false.

\begin{tabular}{lll}
\hline Seifert et al. [74] & $\begin{array}{l}\text { General } \\
\text { medicine/ } \\
\text { Other }\end{array}$ & $\begin{array}{l}\text { Fact extraction } \\
\text { from scientific } \\
\text { literature }\end{array}$ \\
&
\end{tabular}
\begin{tabular}{lll}
\hline Dumitrache [75] & $\begin{array}{l}\text { General } \\
\text { medicine/ }\end{array}$ & $\begin{array}{l}\text { Extracting } \\
\text { annotation }\end{array}$
\end{tabular} Other from medical text

\begin{tabular}{ll}
\hline Parry \& Tsai [76] & $\begin{array}{l}\text { General } \\
\text { medicine/ }\end{array}$ \\
Mortensen et al. & Other \\
{$[77]$} &
\end{tabular}
Semantic tagging of medical documents

Authors present a conceptual framework for scientific fact extraction from literature in different disciplines, to assist researchers who are conducting cross-disciplinary research.

"Dr. Detective" is a game that uses medical experts as a crowd, and is designed to extract annotation and solve disagreements in medical text.

\section{Used CrowdFlower, and uploaded SNOMED} CT relationships and a definition; the crowd Experts were also asked to evaluate relationships.

\begin{tabular}{lll}
\hline Zhai et al. [78] & $\begin{array}{l}\text { General } \\
\text { medicine/ } \\
\text { Other }\end{array}$ & $\begin{array}{l}\text { Natural } \\
\text { language } \\
\text { processing }\end{array}$
\end{tabular}

\begin{tabular}{lll}
\hline Gottlieb et al. & $\begin{array}{l}\text { General } \\
\text { medicine/ } \\
\text { Oth] }\end{array}$ & $\begin{array}{l}\text { Adverse drug } \\
\text { reactions }\end{array}$ \\
\end{tabular}

Used Amazon Mechanical Turk to rank severity of adverse drug reactions (ADRs), which were retrieved from the SIDER2
Using CrowdFlower, crowdsourcing medication names, types and linked attributes of clinical trials that were randomly selected from ClinicalTrials.gov
RESUITS

Authors received responses within hours, and paid US\$ 90 for 400 responses. Out-group responders (those without autism) were more direct in advice, provided superior informational value, and more helpful answers than the in-group responses

1000 statements were collected in $5 \mathrm{~d}$ for less than US $\$ 10$.

1191 responses were collected. While many issues reported were known side effects, some issues were not commonly reported.

Knowledge of ovarian cancer was low among the population studied (which was a US population).

The authors divided players into 'experts' and 'inexperienced' and found that the expert group and considering both groups together significantly enriched knowledge for cancer related diseases, while the inexperienced group's results did not.

Comprehensibility scores were calculated which ranged from $45 \%$ to $98 \%$, and correlated strongly to those in another study uses oral responses with the same pictograms. Misinterpretations were judged to be based on errors within the pictograms themselves, not with the Turkers' abilities.

N/A

The results from the crowd were comparable to those of natural language processing parser.

\section{SNOMED CT relationships were} evaluated (each by 25 workers). The experts and crowd responses were nearly indistinguishable. Errors were identified, which is concerning regarding the biomedical ontologies within SNOMED CT.

High agreement between crowd's annotations for medication names and types, correction of previous annotations and linking medications with their attributes. The authors found that simple voting provided the best form of aggregation.

ADRs ranked as more serious by Turkers were also associated with more deaths in the FDA adverse events reporting system. database. Turkers were provided with 10 pairwise comparisons of ADRs and were asked to select which is worse.

\begin{tabular}{lll}
\hline Khare et al. [5] & $\begin{array}{l}\text { General } \\
\text { medicine/ } \\
\text { Other }\end{array}$ & $\begin{array}{l}\text { Drug indication } \\
\text { curation }\end{array}$ \\
\hline $\begin{array}{l}\text { Dasgupta et al. } \\
{[80]}\end{array}$ & $\begin{array}{l}\text { General } \\
\text { medicine/ } \\
\text { Other }\end{array}$ & $\begin{array}{l}\text { Black market } \\
\text { prices for } \\
\text { prescription } \\
\text { opioids }\end{array}$
\end{tabular}

Used Amazon Mechanical Turk to curate drugs indications. HITs were simplified by asking Turkers to make a judgement of whether a drug label is indicated for a disease, which is highlighted.

3000 HITs were posted from 706 drug labels in $8 \mathrm{~h}$. The aggregated accuracy was $96 \%$, and the total cost was US\$ 1.75 per drug label, which is substantially less expensive that traditional alternatives.

954 reports were obtained through the website. These were compared to prices provided through law enforcements and through the dark web. The prices were highly correlated between the three.
Uses StreetRx (a crowdsourcing website) to obtain prices of prescription opioids. Visitors to the website anonymously post the price they paid for prescription opioids and where they were purchased (and are able to see similar purchases and prices). 
Table 1. Continued

\begin{tabular}{|c|c|c|c|c|}
\hline Referendee & Category & TopIC & How CrowdSOurcing Is USED & Results \\
\hline $\begin{array}{l}\text { Maki } \& \\
\text { Cohstaedt [81] }\end{array}$ & $\begin{array}{l}\text { General } \\
\text { medicine/ } \\
\text { Other }\end{array}$ & $\begin{array}{l}\text { Physical } \\
\text { crowdsourcing } \\
\text { of mosquito } \\
\text { samples }\end{array}$ & $\begin{array}{l}\text { Authors collected physical samples of diptera } \\
\text { culcidae mosquito through crowdsourcing } \\
\text { methods. }\end{array}$ & $\begin{array}{l}\text { Authors received } 110 \text { shipped samples of } \\
\text { mosquitos, } 60 \% \text { of which came from } \\
\text { individuals unknown to laboratory members. } \\
\text { Mosquitos came from areas that were difficult } \\
\text { to reach. }\end{array}$ \\
\hline $\begin{array}{l}\text { McInerney et al. } \\
\text { [82] }\end{array}$ & $\begin{array}{l}\text { General } \\
\text { medicine/ } \\
\text { Other }\end{array}$ & $\begin{array}{l}\text { Logistical } \\
\text { deliveries via } \\
\text { crowdsourcing }\end{array}$ & $\begin{array}{l}\text { Authors propose a distribution method using } \\
\text { the mobility of the local population, and using } \\
\text { information gained by cell towers. Participants } \\
\text { would exchange packages at a point they } \\
\text { normally visit, at a time they normally visit it. }\end{array}$ & $\begin{array}{l}\text { Authors piloted their method, but did not } \\
\text { describe it well. }\end{array}$ \\
\hline $\begin{array}{l}\text { Maier-Hein et al. } \\
\text { [83] }\end{array}$ & $\begin{array}{l}\text { General } \\
\text { medicine/ } \\
\text { Other }\end{array}$ & $\begin{array}{l}\text { Reference } \\
\text { correspondence } \\
\text { in endoscopic } \\
\text { images during } \\
\text { minimally } \\
\text { invasive } \\
\text { surgery }\end{array}$ & $\begin{array}{l}\text { Used Amazon Mechanical Turk to find sets of } \\
\text { corresponding points in endoscopic images, } \\
\text { the results of which were compared to } \\
\text { medical students and experts. }\end{array}$ & $\begin{array}{l}\text { The experiment took } 77 \pm 16 \text { min for } 100 \\
\text { HITs. The authors note that } 10000 \text { annota- } \\
\text { tions could be generated in } 24 \mathrm{~h} \text {. Using a } \\
\text { clustered analysis, the authors obtained an } \\
\text { accuracy that outperformed } 4 \text { of } 5 \text { experts. }\end{array}$ \\
\hline $\begin{array}{l}\text { Behrend et al. } \\
\text { [84] }\end{array}$ & $\begin{array}{l}\text { General } \\
\text { medicine/ } \\
\text { Other }\end{array}$ & $\begin{array}{l}\text { Viability of } \\
\text { crowdsourcing } \\
\text { for organiza- } \\
\text { tional survey } \\
\text { research }\end{array}$ & $\begin{array}{l}\text { Used Amazon Mechanical Turk to collect basic } \\
\text { demographic information and information on } \\
\text { internet knowledge, computer attitudes and } \\
\text { knowledge, goal orientation, and personality. } \\
\text { The results were compared to a control, which } \\
\text { was a traditional psychology participant pool. }\end{array}$ & $\begin{array}{l}\text { Both samples were similar in demographic } \\
\text { characteristics; however, the crowdsourcing } \\
\text { sample was more diverse in education, } \\
\text { employment status and profession. There was } \\
\text { slightly better social desirability and reliability } \\
\text { in the crowdsourced data. The authors } \\
\text { conclude that crowdsourcing is a good data } \\
\text { pool for organizational research. }\end{array}$ \\
\hline Carlson [85] & $\begin{array}{l}\text { General } \\
\text { medicine/ } \\
\text { Other }\end{array}$ & $\begin{array}{l}\text { Clinical trial } \\
\text { protocols }\end{array}$ & $\begin{array}{l}\text { A clinical trial protocol was crowdsourced for } \\
\text { input from physicians and patients. }\end{array}$ & $\begin{array}{l}43 \text { physicians and } 33 \text { patients took part in the } \\
\text { crowdsourcing process to inform development } \\
\text { of the clinical trial's protocol. }\end{array}$ \\
\hline Villaroel [86] & $\begin{array}{l}\text { General } \\
\text { medicine/ } \\
\text { Other }\end{array}$ & $\begin{array}{l}\text { Health care } \\
\text { priority setting }\end{array}$ & $\begin{array}{l}\text { Uses Amazon Mechanical Turk to identify } \\
\text { health care priorities, asking 'what should be } \\
\text { your priority when treating disease.' Turkers } \\
\text { were asked to distribute } 100 \text { points among } \\
5 / 8 \text { questions (which were randomly } \\
\text { assigned) }\end{array}$ & $\begin{array}{l}\text { Dimensions identified include: scale of } \\
\text { disease, household financial effects, social } \\
\text { equity, cost-effectiveness, spillover effects. It is } \\
\text { unclear from the manuscript which rated } \\
\text { most important. }\end{array}$ \\
\hline Meisel et al. [87] & $\begin{array}{l}\text { General } \\
\text { medicine/ } \\
\text { Other }\end{array}$ & $\begin{array}{l}\text { Healthcare } \\
\text { costs }\end{array}$ & $\begin{array}{l}\text { Suggests crowdsourcing health care costs as a } \\
\text { response to higher health care costs for } \\
\text { out-of-pocket health care consumers than } \\
\text { those insured in the US. Specifically, suggests } \\
\text { hosting a website where users can gain access } \\
\text { by posting their (de-identified) medical bills. }\end{array}$ & N/A \\
\hline
\end{tabular}

of malarial fevers, be a better use of funding and reduce drug stock-outs [24]. BioGames was available by Android and online. Gamers were given a tutorial, then in the game had a syringe to 'kill' infected cells and 'collect' healthy ones. The gamers reached an accuracy of 99\% (95.1\% sensitivity, 99.4\% specificity), with the highest level of accuracy being with the largest crowd; however, the authors believe that with a larger crowd, a hybrid algorithm of machine learning and crowdsourcing would perform optimally. Ozcan argues using this method to create gold standard image libraries, for telepathology, point-of-care diagnostics in other conditions and also, to train HCWs in low-income settings [25]. Using the same platform, Feng et al. report on training an education module of the game. The authors used positively or negatively marked cells and had training and diagnostician versions so users could see progress, review misdiagnosed cells and view their accuracy in comparison to their peers. The authors found it was easiest to diagnose negative cells and proposed that in future, laypersons or machines could pre-screen negative cells and send questionable and positive cells to experts for diagnosis. The BioGames project had $>2150$ gamers participate from over 77 countries, providing over 1.5 million diagnoses [26]. A second malaria diagnostic project, MalariaSpot, utilised gamers over a website to also diagnose malaria in RBCs online. In the span of a month, this project had participants in over 95 countries, and over 12000 games played [27]. Participants were asked to tag as many malaria parasites as possible in 1 minute. Like BioGames, the accuracy of MalariaSpot was also over $99 \%$.

Crowdsourcing has also been used to diagnose conditions through grading images. Mitry et al. used the Amazon Mechanical Turk (AMT) platform, which is an online crowdsourcing platform that pays users 
micropayments for small tasks, to grade glaucoma images. The crowd performing the tasks on AMT are called "Turkers". The authors obtained 2540 classifications of 127 disc images, with 83.22\% sensitivity, but only $35 \%-43 \%$ specificity and suggested further micro-izing tasks to improve accuracy [28]. AMT was employed in another study to grade images to screen for diabetic retinopathy, with three phases of grading. The authors found that Turkers were able to sufficiently determine normal vs abnormal, but had trouble grading the severity of retinopathy; however, sensitivity for whether retinopathy was present was $100 \%$ at all stages [29]. Another study used a website to gather a crowd's scores of estrogen receptor in breast cancer tumour tissue. A portion of the tissues was previously scored by a pathologist, allowing the authors to assign users a 'user performance scale' and a reliability/trust score for the crowd. The authors found the crowd's ability was similar to that of a trained pathologists [30]. Gehl et al. used a non-internet based crowdsourcing study to explore skin self-examination (SSE) for atypical moles. The authors recruited 500 participants from a mall, administered a pre-test and post-test and provided each participant with basic SSE techniques. The analysis used a threshold of $19 \%$ of participants to identify the mole as abnormal for it to be considered as such. Using this threshold, the participants correctly identified $90 \%$ of the melanomas and $72 \%$ of the non-melanomas [31]. Xiang et al. attempted to use crowdsourcing to answer the need for a scarcity in medical imaging specialists outside major cities in China. The authors recruited 13 students in 2nd and 3rd year of medical school with a medical imaging major. The average accuracy for the individual was $39.54 \%$; however, the authors were able to increase the accuracy using crowdsourcing algorithms to $56 \%$, and found that machine learning algorithms performed higher. The authors noted that since all the participants were from the same department in the same medical school, the lack of diversity and experience may have contributed to the poor results [32].

Three articles described used crowdsourcing to either assist physicians in providing a diagnosis or to replace physicians in providing a diagnosis. Cheng et al. investigated the feasibility of three crowdsourcing platforms to provide diagnoses: volunteer platforms (ie, Yahoo! Answers), Amazon Mechanical Turk (AMT), and O'Desk. They assessed cases of easy, medium and hard levels of difficulty. The case studies of hardest level of difficulty were taken from CrowdMed.com, which is a website which enables patients with "mystery" diseases to provide their detailed medical information to a crowd of medical experts (including specialists and medical students) who will submit their answers, and the correct diagnostician receiving a reward. The easy and medium levels were taken from another paper, which posted medical questions on Facebook to see if Facebook friends were able to answer $[33,89]$. The authors' attempts at posting on the volunteer sites failed, as they did not receive responses. On AMT, the Turkers were able to solve many of the easy cases but had trouble with the medium difficulty cases, although the authors stated that these may have been poorly described. None of the CrowdMed cases were answered correctly by AMT workers. O'Desk is a crowdsourcing platform that contracts employees, and the authors hired health care professionals. All the easy level questions were answered correctly by O'Desk, but each only answered one medium level case correctly. The original O'Desk workers declined to answer the CrowdMed cases, expressing uncertainty; the second contracted O'Desk workers were unable to answer correctly.

The DocCHIRP (Crowdsourcing Health Information Retrieval Protocol for Doctors) is a mobile application that helps clinician's problem solving at the point-of-care. Sims and colleagues presented the experiences of clinicians using the application. $78 \%$ of clinicians using the application reported benefit on routine patient care, medical education and accurate referrals, as well as diagnosing unusual cases. Some concerns reported by clinicians included lowered productivity, due to responding to the application, and interference with 'off the clock' time, though the latter was only reported among non-users [34]. McComb and Bond also reported on an application that assists clinicians in making diagnoses. Their application, called CoDiagnose, has junior doctors upload case information and receive feedback from a crowd of expert clinicians and it features a built-in e-Learning component. The junior doctors' diagnostic accuracy improved 14\% with the use of the application; however, the authors reported a lack of enthusiasm on part of the expert clinicians about participating [35].

\section{Surveillance}

Another very common purpose to which crowdsourcing is used in health is surveillance, both in the context of research and in emergency situations for programming. A number of articles described pilots or projects that employed crowdsourcing for health surveillance [36-42]. As of 2013, $70 \%$ of the world's population carried a mobile phone [90], making surveillance through mHealth a promising avenue.

Freifeld and colleagues reviewed a number of crowdsourcing platforms that have been used for community surveillance and participatory epidemiology. Frontline SMS, also called Frontline SMS Medic, enables 
users to request needs via SMS. It has been used in Malawi, Burundi, Bangladesh and Honduras. Ushahidi is an open source crowdsourcing application that collects individual reports via web, SMS, and email. It can classify, translate and geotag results. Ushahidi was initially created in response to election violence in Kenya, but it has been used most famously in the aftermath of the Haitian earthquake. It has also been deployed in Uganda, Malawi, Afghanistan, and Zambia. Ushahidi also has a feature for collecting voice reports, which is essential for people who are not literate. Geochat is another crowdsourcing application. It aims to aid in faster and more coordinated responses to disease outbreaks and natural disasters. Team members use the application to communicate their location through SMS, email and web. This information synchronises on all users' devices. The application has been launched in Thailand and Cambodia [36].

Asthmapolis is a GPS-enabled inhaler that is linked to a user's phone and tracks asthma attacks. The application compiles the information from those using its inhalers and generates a risk map for environmental triggers [36]. Freifeld et al. also reported on two other crowdsourcing applications, HealthMap and OutbreaksNearMe, which mapped influenza in the United States using submissions by laypersons. Chunara et al. also reports on a similar tool, FluNearYou, which maps influenza outbreaks using submissions by laypersons and generates a map to identify outbreaks [37].

ClickClinica is an application that was developed to provide General Practitioners (GPs) and Medical Doctors (MDs) indexed guidelines for diseases. Currently, GPs and MDs use the application to diagnose diseases by asking questions about the condition of the patient. The submitted data are graded by the quality of the user information, ie, if the submitter has a medical ID or an institutional email. Over 1000 MDs across the world have been using the application, despite it not being marketed. The application can also be used to increase recruitment for clinical studies through GIS notification of nearby, relevant studies. The authors suggested that this application could be developed into real-time global surveillance based on usage [38].

Qureshi and colleagues described the Jaroka Tele-Health System, which employed Lady Health Workers in rural Pakistan to use SMS/MMS to register patients, report symptoms, acquire prescriptions and connect to specialists. The resulting data was then used to track disease spread and the authors have been able to use the visualised data via crude numbers or rates and identify clustering; the authors found higher rates of disease during times of migration and with internally displaced persons, which could be explained by poor sanitation and overpopulation. They also found increased rates of hypertension in women in these populations [39].

Lwin et al. designed a participatory epidemiology application, called Mo Buzz, in Sri Lanka to combat dengue. Mo Buzz has three components: (i) predictive surveillance; (ii) civic engagement; and, (iii) health communication. The predictive surveillance component uses a machine learning algorithm to determine weather, vector and human data in the form of hotspot maps for the public and for health officials. The civic engagement component involves people reporting breeding sites, symptoms, and bites; these are reflected on the hotspot map. Finally, this information is communicated to the public and to health officials [40].

Chunara et al. use AMT to survey the malaria prevalence in India. Turkers are asked questions regarding malaria symptoms, date of onset, the malaria status of their household members and their awareness of malaria in their communities. The study found that diagnosis peaked in August and this correlated with official reports [41].

A recent study using Global Burden of Disease (GBD) data examined creating a game to scan the GBD database for errors, as algorithms currently used are imperfect. While participants were staff from the Institute for Health Metrics and Evaluation at the University of Washington, and thus not laypersons with no background knowledge, the author found that using gamification increased the accuracy of results by 1.7 times [42]. As only 4\% of infectious diseases have been comprehensively mapped, innovative solutions such as AMT and other crowdsourcing applications detailed above may be useful in providing infectious disease mapping and surveillance [91].

\section{Nutrition}

In the area of nutrition, articles employing crowdsourcing focused on food safety, food labelling, assessing how healthy the meals were, and identifying predictors of obesity [43-50]. Two articles used Yelp reviews to assess food safety in restaurants, one in New York City and the other in Seattle [43,44]. In New York City, the Department of Health and Mental Hygiene received data from Yelp and used computer algorithms to scan the data for probable food poisoning cases. These cases were then reviewed by a food- 
borne epidemiologist, and probable cases were requested for interview. Three outbreaks were discovered by the study [43]. The second article, which uses Yelp reviews for Seattle, tested whether Yelp reviews would be able to predict whether a restaurant would fail its health inspection. The authors found that the Yelp reviews were 82\% accurate predictors for restaurants that would fail health inspections [44].

As food packaging is often complicated and difficult to understand for consumers, Dunford and colleagues created a traffic light application that is populated through crowdsourced submissions in order to enable people in Australia to make healthier choices about their diets [45]. Their application is called "FoodSwitch Australia." Three other articles published efforts to ensure consumers were able to make healthy decisions about the food they eat. Noronha and colleagues, Turner-McGrievy and colleagues and Moorhead and colleagues developed applications to enable crowds to rate the 'healthiness' of food being eaten. Noronha et al.s application, "Platemate" had participants take a photo before and after their meals and asked the crowd to estimate the calories and nutritional composition. They found the estimates of the crowd did not differ significantly from that of experts [46]. Turner-McGrievy et al.'s "EateryApp" had the crowd rating the healthiness of photos of food after 1.5 hours of training. The authors also compared their ratings to those of experts and found a strong correlation between the ratings $(r=0.88, P<0.001)$ [47]. Moorhead also used photos to have a crowd estimate the calories in food, but also developed personalised messages for prevention and management of obesity. They piloted their application with a crowd of 12 non-experts and 12 experts. In both cases, the group estimates were more accurate than any individual estimate [48].

Finally, two articles reported on using crowdsourcing to develop predictors of obesity in a statistical model $[49,50]$. Both articles used reddit to recruit participants and had participants initially answering questions commonly known to be predictors of obesity. Then, they posed new questions, which the group as a whole would answer. Bevelander et al. found that some participants identified examples that were not well documented in literature and suggested that those could be possible new directions for future research. The study also found that only about $7 \%$ of participants posed new questions; the remaining participants answered questions only.

\section{Public health and environment}

Crowdsourcing has been used in public health for research in the areas of tobacco control, physical activity and built environment, environmental health, to shape messaging and for public health related contests [51-58].

Patel et al. created an application to measure the prevalence of smoking in vehicles. The application had a mechanical counter to track passing vehicles, thus providing the denominator, and the person using the application would record each instance of a person smoking in the vehicle. The authors found a prevalence of $2.9 \%$ and had 66 users [51]. Two articles used crowdsourcing for point-of-sale tobacco (POS) monitoring. Ilakkuvan and colleagues used AMT for image annotation. The authors were testing image annotation, rather than monitoring per se, and found that image annotation improved when Turkers were provided with microtasks and given the option to zoom in on photos [52]. The final article examining POS tobacco use physically deployed their crowd to the locations under surveillance. The crowd photographed the stores and answered questions. The authors found high agreement on what the stores sold, but poor agreement on promotions; however, authors noted this could be due to the crowdsourced visitors visiting the stores at different times than the trained experts, when the stores simply had different promotions [53].

Hipp and colleagues used webcams in the United States to capture changes after altering the built environment, for example, by adding a crosswalk or adding a bike lane. The authors then used AMT to annotate the webcam images for the pedestrian and cyclist traffic before and after the changes to the built environment. This was done in order to determine the impact the alteration has had on people's behaviours. The authors found that AMT was a successful method for image annotation and that there were measurable changes after the built environment was altered [54]. Castell et al. used physical crowdsourcing to explore environmental health, and they hoped to have an impact on the health, too. The authors created CITI-SENSE and CITI-SENSE-MOB, two applications which used sensors that were attached to mobile phones that obtained individual-level data on air quality pollution that were GPS-tagged. These data provided users with a map of where pollution was the worst, so they could avoid it [55].

Turner and colleagues employed AMT to test multilingual promotional dental materials (in English and Spanish). They were able to receive feedback from almost 400 Turkers in less than 2 weeks and received 
especially valuable feedback from the Spanish-speaking Turkers regarding the cultural appropriateness and dialects of their messaging [56]. An additional public health messaging project that used crowdsourcing was CrowdoutAIDS, which was a large campaign by the UNAIDS Secretariat that had included youth, both online and offline, from 79 countries in shaping UNAIDS messaging and their priorities for sexual health [57].

Another way crowdsourcing has been used in public health is through contests to draw attention to important causes and promote public engagement. In Philadelphia, a large crowdsourced competition was deployed to bring attention to heart disease through mapping automated external defibrillators (AEDs) $[19,20]$. Through this contest, 1429 AEDs were located through 313 submissions. Data were validated through GPS, door-to-door and photo verifications. The authors were pleasantly surprised that, despite being a social-media based exercise, many older participants contributed. Another exercise that used a crowdsourcing contest to draw attention to a public health concern asked participants to design and develop videos to promote HIV testing in China. Seven eligible videos were submitted in an eight-week time period [58].

\section{Education}

Bow and colleagues reported using crowdsourcing with their pre-clinical medicine students at Johns Hopkins University to create flashcards to improve studying. The professors had questions and respective answers after lectures available on GoogleDrive, which was shared with the class. Students were able to add to questions, add new questions and add to answers. The questions were changed to flashcards using Java, to assist students as study aids. The students' grades improved in comparison with students from the previous year [59]. Another study stated that crowdsourcing could help educators grade students' assignments more fairly, but did not elaborate [92].

\section{Genetics}

In genetics, crowdsourcing has been used for challenges in genetic research, for matching genes to mutations, to identify novel hypotheses through crowdsourced data, and it was proposed as a solution for incidental findings in genomics studies [60-65].

Sage and Dream are two organisations that heavily use crowdsourcing in genetics research. Plenge et al. report on one of their challenges, which was to develop genetic predictors of a response to immunosuppressive therapy in rheumatoid arthritis, using genome-wide association study (GWAS) data. The challenge was team-based, collaborative and open to both public and private contributors. The team that produced the best predictive model would win the challenge [60]. Ewing and colleagues reported on another Dream challenge, which aimed to identify somatic mutations in cancer genomes. The data for this challenge was distributed via GoogleCloud, and the challenge employed a Leaderboard for a competitive aspect. There were 248 submissions by 21 teams in 157 days [61].

Dizeez is a human gene annotation game where players guess which gene causes which disease, out of four options. The game aims to identify gene-disease associations that are known but not present in structured annotation databases. Authors took the genes selected to be associated with a particular disease by many players for further investigation. The authors note that, unfortunately, when players suggest potentially novel associations, they are 'punished' by the game. However, the game was able to successfully identify gene-disease associations [62]. Another gene matching game, EntrezGene, used AMT to match genes from papers and abstracts to their EntrezGene identifier. Turkers were asked to judge whether the gene is associated with a mutation and $20 \%$ of the tasks were controls. In the authors' report, there were problems with the study giving false information to the Turkers but after adjusting for this, the Turkers achieved $82.3 \%$ precision [63].

Kido and Swan reported on using crowdsourced data from MyQuantifiedSelf, which is a personal genomics company, in order to test their novel hypothesis, that some genetic profiles would exhibit a natural capacity for social intelligence. The authors combined citizen science as a form of crowdsourcing and the daily tracking of their "MyFinder" application in order to explore the role of genomics (OXTR gene mutations) on personalities. The authors found that their hypothesis did not appear to be valid, that the increase in the frequency of the G allele did not lead to increased optimism; however, an increase in the frequency of the A allele seemed to lead to decreased optimism. The authors stated that further analyses with larger sample sizes needed to be conducted in order to confirm their hypotheses [64]. 
Finally, as GWAS studies are becoming more prevalent and the probability of incidental findings becomes more likely, Krantz and Berg suggest crowdsourcing as a solution to managing incidental findings. The authors proposed a 'binning system' in genetic studies that employs crowdsourcing, such as through AMT, to separate incidental findings into bins based on their current risk to the individual. For example, clinically actionable results would be placed in "bin 1", while results with a high clinical validity with no actionability would be in "bin 2" and those with no clinical significance would be in "bin 3." The results in bin 2 would need to be re-scored as new advances in medicine are made [65].

\section{Psychology}

There were four articles published in psychology [66-69]. The first explored the viability of using crowdsourcing, specifically via AMT, for studying mental health issues. The authors assessed misrepresentation, inconsistencies in basic demographic information and clinical symptom reporting. The authors found that AMT workers' mental health mirrors that of the general population, other than social anxiety and satisfaction of life scales. AMT workers have an increased social anxiety, which mirrors other internet-based studies, and lower satisfaction with life scales [66]. A second study used AMT to diagnose major depressive disorder (MDD). It asked users for the Twitter account and data-mined their accounts for one-year prior in order to measure user engagement, egocentric social graph, linguistic style, depressive language use, and their mention of using antidepressants. The control was a standard user class. The authors found lower social activity, greater negative emotion, higher self-attentional focus, increased relational and medicinal concerns and heightened expression of religious thoughts among the MDD group [67].

The third study explored the potential for crowdsourcing to adequately respond to discussions in an autism support group by outsourcing the help questions to AMT and having the responses rated against the in-group answers. The AMT answers were rated as more helpful and AMT was seen as a quick way to provide direct and informal emotional support and to broaden perspectives of the autistic community [68]. The final study combined crowdsourcing and data mining, using AMT to generate alternative Life Quality Statements to enable comprehensive data mining for these statements from Twitter [69].

\section{General medicine/other}

Remaining examples of crowdsourcing were in areas of oncology, medical text, various aspects of drugs, including curation, severity of reactions and even black market prices, examples of physical crowdsourcing and other miscellaneous examples [70-76,78-87,93].

Love and colleagues used crowdsourcing to explore women's questions regarding collateral damage from breast cancer treatment. Advocacy organisations collected responses to the questions posed. Many of the women who submitted questions complained of fatigue, memory loss, numbness, anxiety or depression [70]. Another study used crowdsourcing to survey the knowledge of the population about ovarian cancer, using breast cancer as a control. The authors used AMT as a platform and found that $56 \%$ of those surveyed reported no knowledge of ovarian cancer [71]. A third study employed a crowdsourcing game, 'the Cure,' to predict breast cancer survival in order to improve prognostic indicators of breast cancer. Approximately $60 \%$ of players were not knowledgeable about breast cancer. The authors reported that both the expert and the all (expert and non-expert combined) set 'significantly enriched' knowledge, but that the non-expert group alone did not. The responses of the expert group performed well in a Sage contest as well [72].

As a solution to challenges with health literacy and poor comprehension and adherence to text-based medical instructions, Yu and colleagues used AMT to test picture-based medical instructions using existing pictograms from the Internet. The results showed that semantic concepts were difficult to represent in pictures (ie, take with additional water or take in the AM). Turkers with higher levels of education performed better. Yu et al. suggested future studies should use tailor-designed pictograms and explore the interplay between education and responses as well as the role of culture and different countries in ability to comprehend the pictograms [73]. Seifert and colleagues describe conceptual framework for using AMT with the aim to extract facts from interdisciplinary scientific literature in order to help researchers keep track of overlapping topics across disciplines [74]. Another article described the use of gamification to enable both experts and laypersons to complete text extraction, term categorisation, relation extraction and relation categorisation in games called "Dr. Detective" and "Crowd Watson." These games employed crowdsourcing through natural language processing (NLP) and relied on inter-annotator agreement [75]. A third example of NLP using crowdsourcing was Parry et al.'s SNOMED CT (Systemised Nomenclature 
of Medicine-Clinical Terms) which used semantic tagging, similar to Medical Subject Headings (MeSH) terms, in order to help clinicians code free-text documents. SNOMED CT used crowdsourcing, along with a learning algorithm, to imply membership in a particular ontology and the degree of 'fuzziness' the member believes the ontology to be; users then rate how related it is [76]. Crowdsourcing was also used to investigate errors in SNOWMED CT, and when compared to experts, their results were comparable [77].

Crowdsourcing has been used in drug research in various ways, including through NLP, ranking the severity of reactions, curating drug indications and to identify black market prices for drugs. Zhai et al. used Crowdflower, which is a crowdsourcing platform similar to AMT, in order to have a crowd perform NLP tasks that identify medication types, names and link these to their attributes. The authors found that there was high agreement between the crowd's NLP and expert-generated NLP ( 0.87 for medication names, 0.73 for medication types and 0.90 for linking medication to attributes). There were no significant differences between crowdsourced NLPs and experts after developing a "trust" threshold in the analysis, where the Turker meets a threshold to become "trusted" [78]. Gottlieb and colleagues used AMT to rank the severity of almost 3000 adverse drug reactions (ADRs). The authors found that the ADRs ranked most severe were more correlated with death $(r=0.53)$ [79]. Khare et al. aimed to use AMT to create a database of unique drug indications, by providing microtasks to Turkers, asking them to differentiate between whether a drug is indicated for a particular condition or the condition is listed for another reason (ie, it is a risk factor, side effect, contraindication, etc.). The crowd achieved over 90\% accuracy and over 96\% accuracy in identifying drug indications through majority voting [93]. Finally, Dasgupta et al. described the use of crowdsourcing to identify black market prices for opioids through StreetRx. With StreetRx, people were able to anonymously post where, when and the prices that either they or someone they know purchased street drugs for. People were able to access the website without posting, thus drug users were able to see if they were buying their drugs at a fair price. Drug users were motivated to post on the website, as it could prevent them from overpaying for their drugs. The researchers compared the prices on StreetRx to prices reported by law enforcement officials and from a 'dark web' website, Silk Road. The researchers found no significant differences, other than for morphine [80].

Three articles reported on physical instances of crowdsourcing. Maki and Cohnstaedt reported on using crowdsourcing to collect physical samples of mosquitos from a mostly trained crowd. Through crowdsourcing, the authors were able to collect mosquitos in "geographically vital, hard-to-access locations" and achieved a 91\% response rate [81]. McInerney and colleagues reported on a pilot to employ crowdsourcing and Bayesian modelling to deliver items in low- and middle-income countries. The authors described using cell towers during texts and calls to predict temporality, assessing the number of people to achieve geographic coverage and the feasibility to deliver to rural locations and briefly mention a pilot. Despite an in-depth description of the theory behind their crowdsourcing model and the plans for their pilot, the authors hardly discussed their pilot, except to say that it did not perform well and there were delays in all areas (urban and rural) [82]. Finally, Maier-Hein et al. suggested using crowdsourcing for minimally-invasive surgery that required establishing correspondences and was typically done by a medical expert. The authors found that crowdsourcing was comparable to medical experts and could be used to train algorithms [83].

Similar to the psychology studies which tested whether crowdsourcing could be used to sample a population for psychological studies, Behrend et al. explored whether crowdsourcing would be an appropriate population for organisational research, comparing the demographics of a crowd from AMT to a university population. The authors found that the crowdsourcing population was more diverse professionally, and constituted an attractive pool for organisational research [84].

Carlson described a clinical trial protocol that has been reviewed not only by peers, but by patients, using crowdsourcing. He asserted that the clinical trial protocol was faster, and that using the intellectual capacity of patients in addition to researchers would enable the trial to attract participants [85]. Another author advocated for including the general population in health research, but in shaping their research priorities. Villaroel gave an example of a research priority setting exercise that was done in India using AMT. In this exercise, there were significant differences in priorities of those who did and did not vote in the last election, leading the author to assert that elected officials may not have the entire populations' interests at heart [86]. Finally, Meisel et al. suggested an innovative solution using crowdsourcing to combat overcharging at US hospitals. As US hospitals often charge different rates for insured and non-insured customers and can charge exorbitant rates for simple procedures, such as US\$55000 for an appendectomy, the authors suggested creating a database where consumers post their hospital bills. Membership 
in this database could be free once the user has posted one bill. This would help maintain accountability and transparency among the hospitals [87].

\section{DISCUSSION}

Many studies focused on using crowdsourcing for diagnostics or for surveillance. Indeed, it appears that crowdsourcing can be uniquely positioned to improve diagnostics and surveillance of illness. Strategies to improve accuracy included employment of machine-learning algorithms $[24,32,40,76]$, gamification [24-27,42], and establishing thresholds for trustworthiness or questions to weed out malicious workers $[31,63]$.

Crowdsourcing has the potential to improve diagnostics two ways; first, employing a crowd of laypersons and experts through gamification of diagnostics, as shown through BioGames and MalariaSpot [24-27] which have proven to be an effective way arrive at an accurate diagnosis without the need for experts. These games were especially beneficial at identifying RBC that were negative for malarial parasites, which could free expert time, enabling experts to spend time confirming positive blood smears. As Feng et al. and Ozcan suggested, BioGames can be used to train HCWs in LMICs to diagnose RBCs for malaria, which is extremely valuable. While these articles focused on malaria diagnostics, it can easily be imagined that a similar game could be made to diagnose other bloodborne pathogens. If such a game had similar success, online gaming through crowdsourcing could be used to complement traditional laboratory diagnostics and laboratory technicians would spend much less time looking at negative blood smears.

Applications that were developed to use a crowd to grade images had less success than those to identify infected blood cells, though Turkers seemed to be proficient at identifying whether there was presence or absence of retinopathy [29] and when authors employed innovative techniques such as trustworthiness scales or thresholds in their analyses, they achieved better results [30,31]. Other strategies to increase accuracy that have been suggested include providing microtasks; Ilakkuvan et al. reported better results after enabling a zoom feature for image annotation and having micro image annotation tasks [52]. This is synonymous with suggestions of conditions under which to use crowdsourcing that were previously reported $[8,9,15]$.

The second way crowdsourcing can be used in diagnostics in by helping clinicians make diagnoses through applications such as DocCHIRP and CoDiagnose, which had promising results. However, both applications appeared to have some push-back from their 'crowd' of experts [34,35], which questions their sustainability.

Surveillance was the area in which crowdsourcing has been the most successful at the largest scale. Freifeld et al. listed many successful crowdsourcing surveillance applications that are being used for health care in emergency and disaster response situations, such as Ushahidi, Frontline SMS and Geochat [36]. These studies also lowered barriers to entry (for example, through providing multiple ways to submit data, including through voice to text, providing translation services, etc.), which may have contributed to their success [36]. Many of the surveillance applications include some component of civic engagement, either overtly like Mo-Buzz, which uses its predictive surveillance for health communication or less obviously, by relying on mass submissions from laypersons in order to function [40].

Crowdsourcing was found to be useful to predict poor sanitary conditions and foodborne illnesses based on Yelp reviews $[43,44]$, to assess whether meals were healthy, irrelevant of whether the crowd was formed of experts or laypeople $[46,47]$ and to identify predictors of obesity in statistical models for childhood and adulthood obesity $[49,50]$. Applications to help people make healthy choices based on where and what they eat are important. Harrison et al. and Kang et al. have shown that Yelp reviews can be used to direct scarce resources from Public Health Departments to direct food inspectors to the most likely the culprits. Applications that show consumers how healthy their meals are could be important not only in obesity prevention, but also to ensure that consumers are eating a well-balanced diet. Bevelander et al. reported that their crowdsourcing exercise identified predictors of obesity that were not found in the literature and that should be explored in future research [49]. This method to identify predictors for statistical models for both well studied and less commonly researched diseases could be especially beneficial before beginning a study, while deciding which data will be collected.

Some of the research that has taken advantage of crowdsourcing in the public health and environmental health would not have been possible without crowdsourcing. For example, Hipp's characterisation of 
changes in the built environment's effect on physical activity, using web cam footage, would not have been possible without crowdsourcing; it would have been impossible to have the hours and hours of webcam footage annotated. The CITI-SENSE and CITI-SENSE-MOB project, which uses mobile phones to obtain individual level data that are GPS tagged to map air pollution, would also be impossible without crowdsourcing.

Crowdsourcing competitions, for public health or for genetics, have proven to be successful. Merchant et al. and Tucker et al. have used crowdsourcing to draw attention to AEDs in Philadelphia and to HIV testing in China, respectively $[19,20,58]$, whereas Sage and Dream organisations have conducted many challenges for genetic research to identify genetic predictors of immunosuppressive therapy in rheumatoid arthritis or to identify somatic mutations in cancer genomes [60,61]. Kido et al. reported on an innovative combination of citizen science and crowdsourcing, using MyQuantifiedSelf, which takes personal genomics and uses a crowd of people who have MyQuantifiedSelf results to fill in personality tests to test the relationship between genetics and personality [64]. Other authors have included laypersons in gamifying genomics, through EntrezGene, which matches genes to their abstract using AMT [63]. Finally, due to the high number of incidental findings being identified in GWAS studies, Krantz and Berg suggested crowdsourcing as a solution, using a large crowd to go through the findings and putting the findings into 'bins' depending on their clinical validity and actionability [65].

Crowdsourcing has been used to predict survival of cancer, using both laypersons who were not knowledgeable about cancer and experts (though the expert group performed better), which demonstrated that having some knowledge is important when the subject matter is advanced [70]. However, laypeople have been able to perform to expert-level accuracy in other tasks, such as annotation [78,93]. Diagnostics is an area where crowdsourcing is especially promising, as shown by the malaria studies. Interestingly, the most promising studies in diagnostics employed gamification, which was shown to improve accuracy in an unrelated study [24-27,42]. Authors have explored whether crowds of AMT workers display similar characteristics to the general population and concluded that they are appropriate for organisational research and for psychological research, as they differed minimally $[66,67,84]$.

It is important for future work using crowdsourcing to consider the appropriateness of the crowd being used, to ensure the crowd has the capability and the adequate knowledge and also, to design the task and the method of analysis effectively. Freeman found that using gamification (ie, having crowdsourcing activities linked to a game with rewards, scoreboards or some sort of competition) improved accuracy and, examples provided that have used gamification have been quite successful [42]. Other modes of analysis that have been successful include introducing thresholds and degrees of trustworthiness in order for an individuals' answers to be included into the crowd's or for the crowds' answer to be used [30,31]. It is important to note that not all the research, nor all the successful research, in crowdsourcing involved the Internet. Some of the crowdsourcing studies were done in person or involved sending in physical samples [31,81]. Previous definitions of crowdsourcing necessitated using the internet [2], but use of the internet is not compulsory and this is important to stress, especially in the context of global health where use of the internet may not be accessible to all.

\section{CONCLUSION}

Crowdsourcing as a field is still nascent, with the term having only been coined a decade ago [1]. Despite this, it has been used across numerous disciplines in medicine, from diagnosis and surveillance to nutrition, psychology, and even to crowdsourcing minimally invasive surgery. The wideness of uses demonstrates that crowdsourcing applications have been innovative and adaptable. However, many of the crowdsourcing applications have not been used past pilot phases, with the exception of surveillance applications that are used in disaster and emergency relief. These exceptions demonstrate that it is possible to use crowdsourcing at scale; further efforts are needed to take promising crowdsourcing applications to scale in order to provide accessible health care to more communities and individuals rapidly at a low cost. 


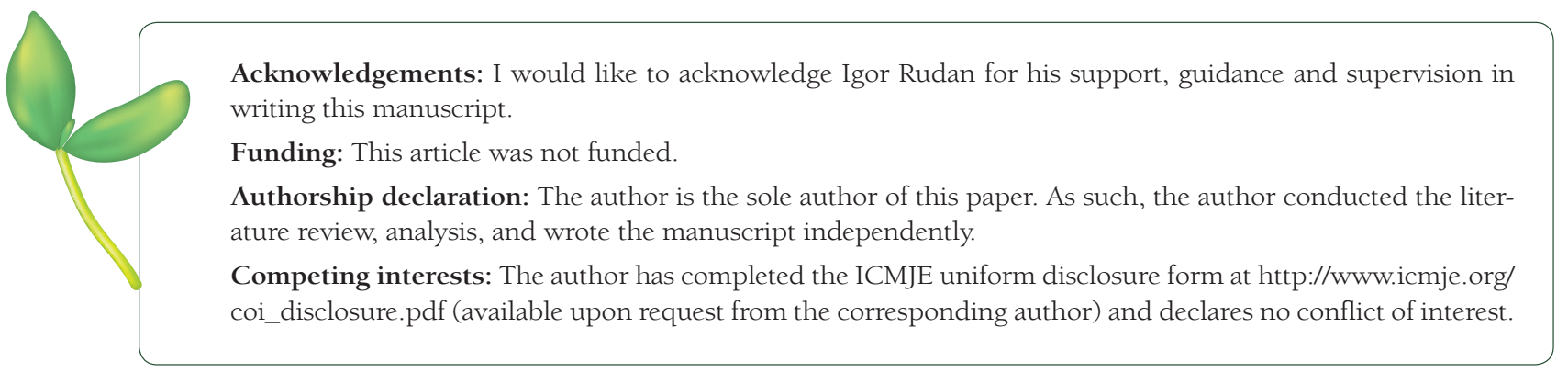

1 Howe J. The rise of crowdsourcing. Wired magazine. 2006;14:1-4.

2 Estellés-Arolas E, González-Ladrón-de-Guevara F. Towards an integrated crowdsourcing definition. J Inf Sci. 2012;38:189200. doi:10.1177/0165551512437638

3 Ranard BL, Ha YP, Meisel ZF, Asch DA, Hill SS, Becker LB, et al. Crowdsourcing - harnessing the masses to advance health and medicine, a systematic review. J Gen Intern Med. 2014;29:187-203. Medline:23843021 doi:10.1007/s11606-0132536-8

4 Nickoloff S. Capsule commentary on Ranard et al., Crowdsourcing-harnessing the masses to advance health and medicine, a systematic review. J Gen Intern Med. 2014;29:186. Medline:24197628 doi:10.1007/s11606-013-2620-0

5 Khare R, Good BM, Leaman R, Su AI, Lu Z. Crowdsourcing in biomedicine: challenges and opportunities. Brief Bioinform. 2016;17:23-32. Medline:25888696 doi:10.1093/bib/bbv021

6 Surowiecki J. The wisdom of crowds. New York: Random House; 2004.

7 Galton F. Vox populi. Nature. 1907;75:450-1. doi:10.1038/075450a0

8 Wazny K. 'Crowdsourcing' ten years in: a review. J Glob Health. 2017;7:020602. Medline:29302322 doi:10.7189/ jogh.07.020601

9 Osella M. A multi-dimensional approach for framing crowdsourcing archetypes. PORTO - Publications Open Repository Torino, Politecnico di Torino; 2014. Available: http://porto.polito.it/2535900/. Accessed: 14 October 2017.

10 Swan M. Crowdsourced health research studies: an important emerging complement to clinical trials in the public health research ecosystem. J Med Internet Res. 2012;14:e46. Medline:22397809 doi:10.2196/jmir.1988

11 Saxton GD, Oh O, Kishore R. Rules of crowdsourcing: models, issues, and systems of control. Inf Syst Manage. 2013;30:220. doi:10.1080/10580530.2013.739883

12 Brabham DC. The myth of amateur crowds A critical discourse analysis of crowdsourcing coverage. Inf Commun Soc. 2012;15:394-410. doi:10.1080/1369118X.2011.641991

13 Luan H, Law J. Web GIS-based public health surveillance systems: A systematic review. ISPRS Int J Geoinf. 2014;3:481506. doi:10.3390/ijgi3020481

14 Brabham DC. Motivations for participation in a crowdsourcing application to improve public engagement in transit planning. J Appl Commun Res. 2012;40:307-28. doi:10.1080/00909882.2012.693940

15 Kittur A. Crowdsourcing, collaboration and creativity. ACM Crossroads. 2010;17:22-6. doi:10.1145/1869086.1869096

16 Kanhere SS. Participatory sensing: Crowdsourcing data from mobile smartphones in urban spaces. Distributed computing and internet technology. New York: Springer; 2013.

17 Prainsack B, Prainsack B, Werner-Felmayer G, Schicktanz S. Understanding participation: the 'citizen science'of genetics. Genetics as Social Practice. 2014:147-64.

18 Thawrani V, Londhe ND, Singh R. Crowdsourcing of Medical Data. IETE Tech Rev. 2014;31:249-53. doi:10.1080/025 64602.2014.906971

19 Merchant RM, Asch DA, Hershey JC, Griffis H, Hill S, Saynisch O, et al. A crowdsourcing, mobile media, challenge to locate automated external defibrillators. Circulation. 2012;126:A57.

20 Merchant RM, Asch DA, Hershey JC, Griffis HM, Hill S, Saynisch O, et al. A crowdsourcing innovation challenge to locate and map automated external defibrillators. Circ Cardiovasc Qual Outcomes. 2013;6:229-36. Medline:23481522 doi:10.1161/CIRCOUTCOMES.113.000140

21 Pedersen J, Kocsis D, Tripathi A, Tarrell A, Weerakoon A, Tahmasbi N, et al, editors. Conceptual foundations of crowdsourcing: a review of IS research. System Sciences (HICSS), 2013 46th Hawaii International Conference on; 2013: IEEE.

22 Zhao YX, Zhu QH. Evaluation on crowdsourcing research: Current status and future direction. Inf Syst Front. 2014;16:41734. doi:10.1007/s10796-012-9350-4

23 Prpic J. Health Care Crowds: Collective Intelligence in Public Health. Prpic J (2015) Health Care Crowds: Collective Intelligence in Public Health Collective Intelligence. Center for the Study of Complex Systems, University of Michigan. 2015. Available: https://ssrn.com/abstract=2570593/. Accessed: 1 July 2016.

24 Mavandadi S, Dimitrov S, Feng S, Yu F, Sikora U, Yaglidere O, et al. Distributed medical image analysis and diagnosis through crowd-sourced games: A malaria case study. PLoS One. 2012;7:e37245. Medline:22606353 doi:10.1371/journal.pone. 0037245

25 Ozcan A. Educational games for malaria diagnosis. Sci Transl Med. 2014;6:233ed9. Medline:24760185 doi:10.1126/ scitranslmed.3009172 
26 Feng S, Woo M, Chandramouli K, Ozcan A, editors. A game-based platform for crowd-sourcing biomedical image diagnosis and standardized remote training and education of diagnosticians. SPIE BiOS; 2015: International Society for Optics and Photonics.

27 Luengo-Oroz MA, Arranz A, Frean J. Crowdsourcing malaria parasite quantification: an online game for analyzing images of infected thick blood smears. J Med Internet Res. 2012;14:e167. Medline:23196001 doi:10.2196/jmir.2338

28 Mitry D, Peto T, Hayat S, Blows P, Morgan J, Khaw T, et al. Crowdsourcing as a screening tool to detect clinical features of glaucomatous optic neuropathy from digital photography. PLoS One. 2015;10:e0117401. Medline:25692287 doi:10.1371/journal.pone.0117401

29 Brady CJ, Villanti AC, Pearson JL, Kirchner TR, Gup O, Shah C. Rapid grading of fundus photos for diabetic retinopathy using crowdsourcing. Invest Ophthalmol Vis Sci. 2014;55:4826.

30 Candido Dos Reis FJ, Lynn S, Ali HR, Eccles D, Hanby A, Provenzano E, et al. Crowdsourcing the general public for large scale molecular pathology studies in cancer. EBioMedicine. 2015;2:681-9. Medline:26288840 doi:10.1016/j.ebiom.2015.05.009

31 Gehl R, King AJ, Grossman D, Jensen JD. Crowdsourcing as an innovative communication strategy in early melanoma detection. Available: https://www.semanticscholar.org/paper/Crowdsourcing-as-an-Innovative-Communication-Strat-Gehl-King/97e37c55a93a43774aa64c33a8e94edc6c9ef465. Accessed: 1 July 2016.

32 Xiang XH, Huang XY, Zhang XL, Cai CF, Yang JY, Li L. Many can work better than the best: Diagnosing with medical images via crowdsourcing. Entropy (Basel). 2014;16:3866-77. doi:10.3390/e16073866

33 Cheng J, Manoharan M, Zhang Y, Lease M. Is there a doctor in the crowd? Diagnosis needed! (for less than \$5). iConference 2015 Proceedings. 2015.

34 Sims MH, Fagnano M, Halterman JS, Halterman MW. Provider impressions of the use of a mobile crowdsourcing app in medical practice. Health Informatics J. 2016;22:221-31. Medline:25167866 doi:10.1177/1460458214545896

35 McComb S, Bond RR. CoDiagnose: Interactive software to harness collaborative diagnoses and to increase diagnostic accuracy amongst junior physicians. Technol Health Care. 2015;23:243-56. Medline:25669211 doi:10.3233/THC150892

36 Freifeld CC, Chunara R, Mekaru SR, Chan EH, Kass-Hout T, Iacucci AA, et al. Participatory epidemiology: use of mobile phones for community-based health reporting. PLoS Med. 2010;7:e1000376. Medline:21151888 doi:10.1371/journal. pmed.1000376

37 Chunara R, Aman S, Smolinski M, Brownstein JS. Flu near you: an online self-reported influenza surveillance system in the USA. Online J Public Health Inform. 2013;5:e133. doi:10.5210/ojphi.v5i1.4456

38 Michael BD, Geleta D. Development of ClickClinica: a novel smartphone application to generate real-time global disease surveillance and clinical practice data. BMC Med Inform Decis Mak. 2013;13:70. Medline:23816161 doi:10.1186/14726947-13-70

39 Qureshi H, Keyani S. Babar Q-u-A, Mumtaz AA, editors. Monitoring disease outbreak through geographical representation in rural areas. Developments in E-systems Engineering (DeSE), 2011; 2011: IEEE.

40 Lwin MO, Vijaykumar S, Fernando ON, Cheong SA, Rathnayake VS, Lim G, et al. A 21st century approach to tackling dengue: Crowdsourced surveillance, predictive mapping and tailored communication. Acta Trop. 2014;130:100-7. Medline:24161879 doi:10.1016/j.actatropica.2013.09.021

41 Chunara R, Chhaya V, Bane S, Mekaru SR, Chan EH, Freifeld CC, et al. Online reporting for malaria surveillance using micro-monetary incentives, in urban India 2010-2011. Malar J. 2012;11:43. Medline:22330227 doi:10.1186/14752875-11-43

42 Freeman MK. The use of crowdsourcing and the role of game mechanics in identifying erroneous disease burden estimates: University of Washington; 2013.

43 Harrison C, Jorder M, Stern H, Stavinsky F, Reddy V, Hanson H, et al. Using online reviews by restaurant patrons to identify unreported cases of foodborne illness. - New York City, 2012-2013. Morbidity and Mortality Weekly Report. 2014;63:441-5. Medline:24848215

44 Kang JS, Kuznetsova P, Luca M, Choi Y, editors. Where not to eat? Improving public policy by predicting hygiene inspections using online reviews. EMNLP; 2013: Citeseer.

45 Dunford E, Trevena H, Goodsell C, Ng KH, Webster J, Millis A, et al. FoodSwitch: A mobile phone app to enable consumers to make healthier food choices and crowdsourcing of national food composition data. JMIR Mhealth Uhealth. 2014;2:e37. Medline:25147135 doi:10.2196/mhealth.3230

46 Noronha J, Hysen E, Zhang H, Gajos KZ, editors. Platemate: crowdsourcing nutritional analysis from food photographs. Proceedings of the 24th annual ACM symposium on User interface software and technology; 2011: ACM.

47 Turner-McGrievy GM, Helander EE, Kaipainen K, Perez-Macias JM, Korhonen I. The use of crowdsourcing for dietary self-monitoring: crowdsourced ratings of food pictures are comparable to ratings by trained observers. J Am Med Inform Assoc. 2015;22:e112-9. Medline:25092793

48 Moorhead A, Bond R, Zheng H. Smart Food: Crowdsourcing of experts in nutrition and non-experts in identifying calories of meals using smartphone as a potential tool contributing to obesity prevention and management. 2014. Bioinformatics and Biomedicine. IEEE.

49 Bevelander KE, Kaipainen K, Swain R, Dohle S, Bongard JC, Hines PD, et al. Crowdsourcing novel childhood predictors of adult obesity. PLoS One. 2014;9:e87756. Medline:24505310 doi:10.1371/journal.pone.0087756

50 Bongard JC, Hines PDH, Conger D, Hurd P, Lu ZY. Crowdsourcing Predictors of Behavioral Outcomes. IEEEE Transactions on Systems Man Cybernetics-Systems. 2013;43:176-85. doi:10.1109/TSMCA.2012.2195168 
51 Patel V, Nowostawski M, Thomson G, Wilson N, Medlin H. Developing a smartphone 'app' for public health research: the example of measuring observed smoking in vehicles. J Epidemiol Community Health. 2013;67:446-52. Medline:23443959 doi:10.1136/jech-2012-201774

52 Ilakkuvan V, Tacelosky M, Ivey KC, Pearson JL, Cantrell J, Vallone DM, et al. Cameras for public health surveillance: A methods protocol for crowdsourced annotation of point-of-sale photographs. JMIR Res Protoc. 2014;3:e22. Medline:24717168 doi:10.2196/resprot.3277

53 Kim AE, Lieberman A, Dench D. Case Study Comparing Data Collected via Crowdsourcing vs. Trained Data Collectors for Tobacco Retail Audits. 2013.

54 Hipp JA. Physical activity surveillance and emerging technologies. Revista Brasileira de Atividade Física \& Saúde. 2013;18:2-4. doi:10.12820/2317-1634.2013v18n1p2

55 Castell N, Liu H-Y, Schneider P, Cole-Hunter T, Lahoz W, Bartonova A. Towards a personalized environmental health information service using low-cost sensors and crowdsourcing. 2015. EGU General Assembly.

56 Turner AM, Kirchhoff K, Capurro D. Using crowdsourcing technology for testing multilingual public health promotion materials. J Med Internet Res. 2012;14:e79. Medline:22664384 doi:10.2196/jmir.2063

57 Hildebrand M, Ahumada C, Watson S. CrowdOutAIDS: crowdsourcing youth perspectives for action. Reprod Health Matters. 2013;21:57-68. Medline:23684188 doi:10.1016/S0968-8080(13)41687-7

58 Tucker J, Galler S, Team OS, Han L. Spurring innovation in designing HIV testing programs: A crowdsourcing contest-based approach. Ann Glob Health. 2014;80:223-4. doi:10.1016/j.aogh.2014.08.165

59 Bow HC, Dattilo JR, Jonas AM, Lehmann CU. A crowdsourcing model for creating preclinical medical education study tools. Acad Med. 2013;88:766-70. Medline:23619061 doi:10.1097/ACM.0b013e31828f86ef

60 Plenge RM, Greenberg JD, Mangravite LM, Derry JM, Stahl EA, Coenen MJ, et al. Crowdsourcing genetic prediction of clinical utility in the Rheumatoid Arthritis Responder Challenge. Nat Genet. 2013;45:468-9. Medline:23619782 doi:10.1038/ng.2623

61 Ewing AD, Houlahan KE, Hu Y, Ellrott K, Caloian C, Yamaguchi TN, et al. Combining tumor genome simulation with crowdsourcing to benchmark somatic single-nucleotide-variant detection. Nat Methods. 2015;12:623-30. Medline:25984700 doi:10.1038/nmeth.3407

62 Loguercio S, Good BM, Su AI. Dizeez: an online game for human gene-disease annotation. PLoS One. 2013;8:e71171. Medline:23951102 doi:10.1371/journal.pone.0071171

63 Burger JD, Doughty E, Khare R, Wei CH, Mishra R, Aberdeen J, et al. Hybrid curation of gene-mutation relations combining automated extraction and crowdsourcing. Database (Oxford). 2014;2014:bau094. Medline:25246425 doi:10.1093/ database/bau094

64 Kido T, Swan M, editors. Exploring the Mind with the Aid of Personal Genome-Citizen Science Genetics to Promote Positive Well-Being. 2013 AAAI Spring Symposium Series; 2013.

65 Krantz MS, Berg JS. Crowdsourcing to define the clinical actionability of incidental findings of genetic testing. N C Med J. 2013;74:501-2. Medline:24316777

66 Shapiro DN, Chandler J, Mueller PA. Using Mechanical Turk to study clinical populations. Clin Psychol Sci. 2013;1:21320. doi:10.1177/2167702612469015

67 De Choudhury M, Gamon M, Counts S, Horvitz E, editors. Predicting Depression via Social Media. ICWSM; 2013.

68 Hong H, Gilbert E, Abowd GD, Arriaga RI, editors. In-group questions and out-group answers: Crowdsourcing daily living advice for individuals with autism. Proceedings of the 33rd Annual ACM Conference on Human Factors in Computing Systems; 2015: ACM.

69 Yang C, Srinivasan P, editors. Translating surveys to surveillance on social media: methodological challenges \& solutions. Proceedings of the 2014 ACM conference on Web science; 2014: ACM.

70 Love SM, Obidegwu A, Fischetti CA. Abstract P1-09-31: Crowdsourcing the collateral damage from breast cancer treatment. Cancer Res. 2015;32:S110.

71 Carter RR, DiFeo A, Bogie K, Zhang GQ, Sun JY. Crowdsourcing awareness: exploration of the ovarian cancer knowledge gap through Amazon Mechanical Turk. PLoS One. 2014;9:e85508. Medline:24465580 doi:10.1371/journal. pone.0085508

72 Good BM, Loguercio S, Griffith OL, Nanis M, Wu C, Su AI. The cure: design and evaluation of a crowdsourcing game for gene selection for breast cancer survival prediction. JMIR Serious Games. 2014;2:e7. Medline:25654473 doi:10.2196/ games. 3350

$73 \mathrm{Yu}$ B, Willis M, Sun PY, Wang J. Crowdsourcing participatory evaluation of medical pictograms using Amazon Mechanical Turk. J Med Internet Res. 2013;15:e108. Medline:23732572 doi:10.2196/jmir.2513

74 Seifert C, Granitzer M, Höfler P, Mutlu B, Sabol V, Schlegel K, et al. Crowdsourcing fact extraction from scientific literature. Human-Computer Interaction and Knowledge Discovery in Complex, Unstructured, Big Data: Springer; 2013. p. 160-72.

75 Dumitrache A, Aroyo L, Welty C, Sips R-J, Levas A. "Dr. Detective": combining gamification techniques and crowdsourcing to create a gold standard in medical text. 12th International Semantic Web Conference Proceedings of the 1st International Workshop on Crowdsourcing the Semantic Web (CrowdSem 2013); 2013: Citeseer.

76 Parry DT, Tsai TC. Crowdsourcing techniques to create a fuzzy subset of SNOMED CT for semantic tagging of medical documents. Soft Comput. 2012;16:1119-27. doi:10.1007/s00500-011-0787-z

77 Mortensen JM, Minty EP, Januszyk M, Sweeney TE, Rector AL, Noy NF, et al. Using the wisdom of the crowds to find critical errors in biomedical ontologies: a study of SNOMED CT. J Am Med Inform Assoc. 2015;22:640-8. Medline:25342179 doi:10.1136/amiajnl-2014-002901 
78 Zhai H, Lingren T, Deleger L, Li Q, Kaiser M, Stoutenborough L, et al. Web 2.0-based crowdsourcing for high-quality gold standard development in clinical natural language processing. J Med Internet Res. 2013;15:e73. Medline:23548263 doi:10.2196/jmir.2426

79 Gottlieb A, Hoehndorf R, Dumontier M, Altman RB. Ranking adverse drug reactions with crowdsourcing. J Med Internet Res. 2015;17:e80. Medline:25800813 doi:10.2196/jmir.3962

80 Dasgupta N, Freifeld C, Brownstein JS, Menone CM, Surratt HL, Poppish L, et al. Crowdsourcing black market prices for prescription opioids. J Med Internet Res. 2013;15:e178. Medline:23956042 doi:10.2196/jmir.2810

81 Maki EC, Cohnstaedt LW. Crowdsourcing for large-scale mosquito (Diptera: Culicidae) sampling. Can Entomol. 2015;147:118-23. doi:10.4039/tce.2014.27

82 McInerney J, Rogers A, Jennings NR. Crowdsourcing physical package delivery using the existing routine mobility of a local population. Mobile Phone Data for Development-Analysis of Mobile Phone Datasets for the Development of Ivory Coast. 2014:447-56.

83 Maier-Hein L, Mersmann S, Kondermann D, Stock C, Kenngott HG, Sanchez A, et al. Crowdsourcing for reference correspondence generation in endoscopic images. Medical Image Computing and Computer-Assisted Intervention-MICCAI 2014: Springer; 2014. p. 349-56.

84 Behrend TS, Sharek DJ, Meade AW, Wiebe EN. The viability of crowdsourcing for survey research. Behav Res Methods. 2011;43:800-13. Medline:21437749 doi:10.3758/s13428-011-0081-0

85 Carlson RH. Crowdsourcing Clinical Trial Protocols. Oncology Times. 2014;36:1-31. doi:10.1097/01. COT.0000459127.99151.01

86 Villarroel JA. Collective intelligence in public health policy making: crowdsourcing health care priorities setting. Available: https://sites.lsa.umich.edu/collectiveintelligence/wp-content/uploads/sites/176/2015/02/Villarroel-CI-2015-Abstract.pdf. Accessed: 1 July 2017.

87 Meisel ZF, VonHoltz LAH, Merchant RM. Crowdsourcing healthcare costs: Opportunities and challenges for patient centered price transparency. Healthc (Amst). 2016;4:3-5. Medline:27001090 doi:10.1016/j.hjdsi.2015.06.004

88 Brady CJ, Villanti AC, Pearson JL, Kirchner TR, Gupta OP, Shah CP. Rapid grading of fundus photographs for diabetic retinopathy using crowdsourcing. J Med Internet Res. 2014;16:e223. Medline:25356929 doi:10.2196/jmir.3807

89 Folkestad L, Brodersen JB, Hallas P, Brabrand M. Laypersons can seek help from their Facebook friends regarding medical diagnosis. Ugeskr Laeger. 2011;173:3174-7. Medline:22142603

90 Kass-Hout TA, Alhinnawi H. Social media in public health. Br Med Bull. 2013;108:5-24. Medline:24103335 doi:10.1093/ $\mathrm{bmb} / \mathrm{ldt} 028$

91 Hay SI, Battle KE, Pigott DM, Smith DL, Moyes CL, Bhatt S, et al. Global mapping of infectious disease. Philos Trans R Soc Lond B Biol Sci. 2013;368:20120250. Medline:23382431 doi:10.1098/rstb.2012.0250

92 Chan C, Holosko MJ. An overview of the use of Mechanical Turk in behavioral sciences implications for social work. Res Soc Work Pract. 2015;26:441-8. doi:10.1177/1049731515594024

93 Khare R, Burger JD, Aberdeen JS, Tresner-Kirsch DW, Corrales TJ, Hirchman L, et al. Scaling drug indication curation through crowdsourcing. Database (Oxford). 2015;2015:bav016. Medline:25797061 doi:10.1093/database/bav016 